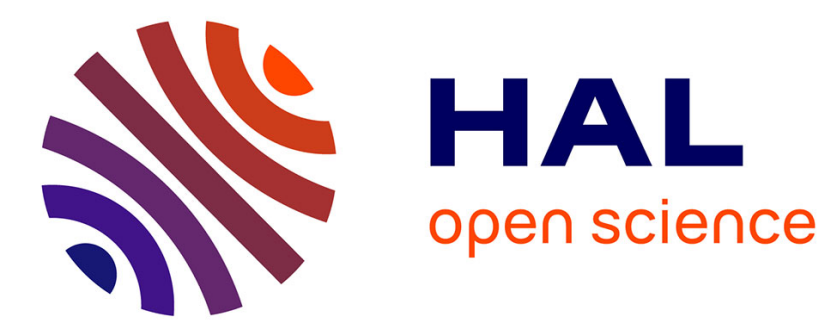

\title{
Sequence Phenomena and Double Access Readings Generalized
}

\author{
Philippe Schlenker
}

\section{To cite this version:}

Philippe Schlenker. Sequence Phenomena and Double Access Readings Generalized. Guéron \& Lecarme. The Syntax of Time, MIT Press, 2003. ijn_00000462

\section{HAL Id: ijn_00000462 \\ https://hal.science/ijn_00000462}

Submitted on 6 Apr 2004

HAL is a multi-disciplinary open access archive for the deposit and dissemination of scientific research documents, whether they are published or not. The documents may come from teaching and research institutions in France or abroad, or from public or private research centers.
L'archive ouverte pluridisciplinaire HAL, est destinée au dépôt et à la diffusion de documents scientifiques de niveau recherche, publiés ou non, émanant des établissements d'enseignement et de recherche français ou étrangers, des laboratoires publics ou privés. 


\section{Sequence Phenomena and Double Access Readings Generalized (Two Remarks on Tense, Person and Mood) ${ }^{1}$ Philippe Schlenker (UCLA \& Institut Jean-Nicod) November 2002}

\section{Introduction}

Some analogies have been observed over the years between the semantics of pronouns, tenses and moods. Thus Partee 1973 suggested that tenses have all the uses that pronouns do, and should thus receive the same abstract analysis; her argument was then extended to mood in Stone 1997. Consider for instance the deictic use of pronouns, illustrated in (1)a. Partee's and Stone's suggestion was that tenses and moods have an entirely analogous use, illustrated in (1)b-c (in the logical forms, $\square$ represents negation and $P$ represents the past tense operator):

(1) a. She left me

(Partee 1973)

a1. Left-me $\left(\mathrm{x}_{0}\right)$

b. I didn't turn off the stove

(Partee 1973)

b1. \# $\square$ PTurn-off-the-stove

b2. \#P口T

b3. $\square \mathrm{T}\left(\mathrm{t}_{0}\right)$

c. My neighbors would kill me

(Stone 1997)

c1. $\mathrm{K}\left(\mathrm{w}_{0}\right)$

(1)a can be used even when she has no linguistic antecedent, provided that some female individual is salient in the extra-linguistic context (in Partee's scenario, a man sitting on a bench is holding his head in his hands as he utters the sentence; one can infer without difficulty which individual is meant by she). This can be analyzed as in (1)a1, where a variable is left free and receives a value from the extra-linguistic context. Partee's observation was that the same analysis carries over to tense in (1)b, uttered by someone who has just left her house. Her claim was that none of the analyses offered by a standard modal theory will do; for in such theories a past tense is analyzed as a temporal operator with existential force, as in b1 and b2. However the sentence can neither have the logical form in b1 ('at no point in the past did I turn off the stove' - uninformative because trivially false) nor that in b2 ('there is some point in the past at which I didn't turn off the stove' - uninformative

${ }^{1}$ The first part of this paper develops in greater detail suggestions that are only sketched in Schlenker 2002a. As is made clear in the text, the second part of the account owes much to Abusch 1997 and Heim 1994b, although the technical implementation is rather different. Thanks to O. Percus for discussion, to B. Lenoir for help with the French data, and to J. Lecarme and J. Guéron for helpful comments. This paper was already completed when I read the first version of von Stechow 2002, which offers a different -and very elegantimplementation of ideas related to those I develop in Section 1. 
because trivially true). The problem disappears if the past tense is treated as a free time variable, whose value is provided by the context of utterance, as in (1)b3. Finally, in the scenario for (1)c, due to Stone 1997, one of the guests at a party starts turning up the volume of the stereo. The host disapproves, and utters (1)c. The intended meaning is that 'my neighbors would kill me in that world or in those worlds in which your action is completed'. The extralinguistic context (the guest's gesture) is enough to provide a value for the free variable in (1)c1. A natural conclusion is that if pronouns are analyzed as introducing (free or bound) individual variables in syntactic representations, tense and mood should, by parity of reasoning, be taken to introduce time and world variables, and not operators, as posited in Modal and Tense Logic ${ }^{2}$.

Once pronouns, tenses and moods are uniformly treated as variables, it is natural to suggest that pronominal, temporal and modal features should also be analyzed in a uniform fashion. Cooper 1983 treated pronominal features such as gender as presuppositions on the value of individual variables. Extending this view to tense, Heim 1994b suggested that temporal features are presuppositions on the values of time variables; and some have tried to extend a similar analysis to mood (see von Fintel 1997; Schlenker 2002b). Further attempts have sought to relate the cross-linguistic typologies found in the temporal and in the personal or modal domains. I tried to argue in Schlenker 2002a that both tense and person display a distinction between indexicals that can be evaluated only with respect to the context of the actual speech act ('unshiftable indexicals') and indexicals that can be evaluated either with respect to the context of the actual speech act or with respect to the context of a reported speech act ('shiftable indexicals'). While the English present tense and the English first person pronoun belong to the first category, the Russian present tense and the Amharic first person marker belong to the second, as is suggested by the following data:

\footnotetext{
${ }^{2}$ As is well-known, the pronouns-as-variables theory encounters problems in the analysis of 'donkey sentences'. These can be solved by developing systems of dynamic semantics, as in Kamp 1981 or Heim 1982; or by re-analyzing pronouns as concealed definite descriptions, as is done (among others) in Heim 1990, Schein 1993 and Ludlow 1994. In the latter case, pronominal, temporal and modal features should be seen as falling within the restrictor of the definite description. On a Strawsonian or Fregean treatment of 'the' it would then follow that these features trigger presuppositions.
} 
(2)

a. petja $\mathrm{i}_{\mathrm{i}}$ skazal, ctb on $\mathrm{on}_{\mathrm{i}}$ placlt

(Russian)

Petja $_{i}$ said that he $e_{i}$ is-crying

'Petja said that he was crying [at the time of his utterance]'

$a^{\prime}$. \#Peter ${ }_{i}$ said a week ago that he $\mathrm{i}_{\mathrm{i}}$ is crying.

b. $j \boxminus n \quad j[\square n a \quad n \square-n \boxminus \square \quad y \square$-all

John hero be.PF-1SO 3M.say-AUX.3M

(Amharic)

"John says that he is a hero"

$\mathrm{b}^{\prime} . \neq \mathrm{J}$ ohn says that I am a hero

In (2)a the tense of the embedded clause can (in an intuitive sense) denote the time of Petja's utterance; this is not in general possible in English, as is seen by the deviance of (2)a'. ${ }^{3}$ Similarly in (2)b the Amharic first person pronoun may denote the speaker of the reported speech act, something which is not possible in English, as shown by (2) $\mathbf{b}^{14}$.

If at least some of the preceding observations are on the right track, one should ask how far the analogy between tenses, pronouns and moods really extends. In this paper I offer two limited suggestions: the first one is that, under certain commonly held assumptions, the device of 'Sequence of Tense rules', postulated to account for Tense Agreement in indirect discourse, should be extended to person and mood. The second is that so-called Double Access Readings in the tense domain have a purely modal counterpart, which I seek to analyze by offering a generalization of the theory of tense developed in Abusch 1997. In the spirit of Partee 1973, Kratzer 1998, Stone 1997 and Bittner 2001, the goal will thus be to enlarge somewhat the list of phenomena that can receive a unified analysis across tense, person and mood.

To put things in sharper focus, let us first consider the original motivation for positing Tense Agreement rules ('Sequence of Tense rules'). Without such rules one could claim, as Enç 1987 did, that temporal features are always semantically interpreted - no doubt an attractive theory. That it isn't viable is shown by the following example, originally due to Kamp \& Rohrer (the present version is slightly modified from Abusch 1997):

(3) John decided yesterday that tomorrow he would tell his mother that they were having their last meal together.

\footnotetext{
${ }^{3}$ In Double Access Readings in English, a present tense embedded under an attitude verb in the past tense may denote an interval that includes the time of utterance, but only if it also includes the time of the attitude (or to put it more precisely: the time that the agent thinks is the time of his thought or speech act). This standard observation is discussed below.

${ }^{4}$ A further observation is that the distinction between ' shiftable' and 'unshiftable' indexicals is naturally extended to encompass indexicals that are obligatorily shifted, and are thus systematically evaluated with respect to the context of a reported speech act. A natural suggestion is that logophoric pronouns (as found for instance in Ewe, see Clements 1975) belong to this third category. I argued in Schlenker 2002a that the latter also includes a kind of 'logophoric mood', the German 'Konjunktiv 1', which is in some ways formally analogous to logophoric pronouns.
} 
Since the meal is supposed to take place tomorrow, its time of occurrence follows each of the moments that are salient in the discourse, and in particular the time of utterance. Thus any theory that claims that the past tense of were expresses anteriority with respect to some other moment (e.g. the time of utterance) is bound to go wrong in this case. As a first approximation, the facts can be handled by postulating that a tense $\mathrm{T}_{2}$ embedded under an attitude verb with tense $\mathrm{T}_{1}$ may inherit in a purely morphological fashion (i.e. without semantic consequences) the tense features of $T_{1}$ if $T_{1}$ and $T_{2}$ are interpreted as being (in a sense to be clarified below) coreferential. Alternatively, one could say, following Ogihara 1996, that the tense features of $\mathrm{T}_{2}$ are present throughout the syntactic derivation, but are eliminated right before semantic interpretation by a rule of Tense Deletion. For our purposes both formulations will do: if would is analyzed as the past tense of will (as is commonly assumed), the representation in (4) is obtained, where will-ed inherits its past tense features from decid-ed, and transmits them in turn to were. Since the inheritance process is morphological, the tense features of were do not have to be interpreted semantically, as is desired: (4) John decid-ed that he will-ed tell his mother that they were having their last meal
together.

$$
\text { agreement agreement }
$$

In the first part of this paper, I suggest (following Heim 1994a) that in exactly the same syntactic configuration the masculine features of he and himself in (5) can also be ignored. And we will see that the same facts appear to hold, mutatis mutandis, of the indicative mood features of $i$ in (6):

(5) a. John hopes that he will buy himself a car

b. John hopes PRO to buy himself a car

(6) John is thinking (at this very moment) that Mary is pregnant.

In the second part of this paper, I consider what happens when Tense Agreement fails to hold, especially when a present tense is embedded under a past tense attitude verb. A grammatical sentence can then be obtained, but it has a peculiar ('Double Access') reading whereby the agent's attitude somehow has to be both about the time (that he thinks is the time) of this thought act and about the time of the speaker's utterance; this explains why (7)a (by contrast with (7)a') is incoherent, since John presumably knows that a pregnancy cannot span two years. No such effect holds when the Sequence of Tense rule is applied, as shown by (7)a'-b':

(7) a. \#Two years ago John claim-ed that Mary is pregnant.

b. ${ }^{\mathrm{Ok}}$ Two days ago John claim-ed that Mary is pregnant.

a'. ${ }^{\mathrm{k}}$ Two years ago John claim-ed that Mary was pregnant.

b'. Ok Two days ago John claim-ed that Mary was pregnant.

We will see that an analogous contrast can be replicated with mood, as in the French examples in (8): 
(8) a. Je crains qu'un jour Jean apprenne que Marie est enceinte

Ifear-ind that some day Jean learn-subj that Marie is-ind pregnant

'I am afraid some day Jean will learn that Mary is pregnant'

b. Je crains qu'un jour Jean apprenne que Marie soit enceinte

I fear-ind that some day Jean learn-subj that Marie is-subj pregnant

'I am afraid some day Jean will learn that Mary is pregnant'

The first verb ('fear') serves to force the appearance of subjunctive mood on the second ('learn'). The speaker has the option of applying mood agreement between the second verb ('learn') and the third ('be pregnant'), marking the latter as subjunctive; or he may simply mark the last verb as indicative. We will see that in the latter case the world equivalent of a Double Access Reading is obtained, whereby what Jean learns in the situations that the speaker fears must be both about the situations in question and about the actual world (similar examples, in fact more robust ones, can be replicated with a morphological present or past tense interpreted in a purely modal fashion in the antecedent of a conditional, as in (31) and (32) below; the advantage of concentrating on French is that examples with a morphological subjunctive are available in a broader range of contexts). I will try to account for this observation by developing a somewhat generalized version of the theory of Abusch 1997, and especially of her 'Upper Limit Constraint'.

Although I have tried to keep the following discussion reasonably

precise, some of the formal details have been omitted; they are more fully laid out in the Appendix, where a full fragment is developed. The reader will observe that the syntax I assume throughout is much simpler than that of English or French. This is an idealization, designed to make the semantic discussion more tractable. I trust that the basic mechanisms I posit - in particular, my rules of agreement- can be adapted to any reasonable syntactic analysis. (See von Stechow 2002 for a more realistic implementation of related ideas).

\section{Tense Agreement, Person Agreement, Mood Agreement}

\subsection{The Necessity of Rules of Person Agreement}

Why should one need rules of person agreement to handle attitude verbs? The argument, first made (to my knowledge) in Heim 1994a, has the following logic:

(i) In some cases, a pronoun embedded under an attitude verb cannot literally be interpreted as being 'De Re', and thus coreferential with an argument of the super-ordinate clause. This arises when the pronoun is read 'De $\mathrm{Se}$ ', and thus unambiguously reports a first person thought.

(ii) Still, in these cases the embedded pronoun agrees in features with the corresponding argument of the super-ordinate clause (i.e. an individual pronoun agrees with the subject of the embedding verb, a time argument agrees with the super-ordinate tense, etc.). This holds in some cases in which a 
presupposition failure would be predicted if the pronominal features were semantically interpreted.

\subsubsection{De Se Readings}

To see why a problem arises in the first place, consider the following example, first analyzed in a different guise by Morgan 1970 and Chierchia 1987 (this version is from Schlenker 2002a):

(9) Situation: John is so drunk that he has forgotten that he is a candidate in the election. He watches someone on TV and finds that that person is a terrific candidate, who should definitely be elected. Unbeknownst to John, the candidate he is watching on TV is John himself.

a. True: John hopes that he will be elected

b. False/\#: John hopes PRO to be elected [Ok if the thought was: 'I should be elected']

In this far-fetched situation a surprising nuance appears between (9)a and (9)b. Somehow using the infinitive entails that John's hope was of the form I will be elected ('De Se reading'), rather than He will be elected, where he refers unbeknownst to him- to John himself. Lest the reader think that this contrast can be reduced to the distinction between 'bound variable readings' and 'accidental coreference', I note (with virtually everyone who has worked on this topic) that this is not so. If several candidates watch themselves on different TVs without recognizing themselves, one may say truly that 'Every candidate hopes that he will be elected', but not that 'Every candidate hopes to be elected'. The De Se/De Re distinction is preserved in sentences that only have a bound variable reading.

Chierchia 1987 analyzed the problem by suggesting that PRO, the unpronounced subject of an infinitive, can only be read De Se. His solution was to revise the semantics of attitude verbs, and to suggest that (9)b doesn't simply establish a relation between John and the set of worlds $w$ in which John is elected, but rather a relation between John and the set of individual/world pairs $<x, w>$ such that $x$ is elected in w. In other words, John doesn't simply hope to live in a world in which John is elected; rather, he wants to be one of the individuals that get elected (or to put it differently he stands in the relation of 'hope' to the set of pairs $<x, w>$ such that the individual $\mathrm{x}$ is elected in the world $\mathrm{w}>$. This approach is naturally extended to tense (as in Abusch 1997), so that in the end hope is taken to establish a relation between John and the set of triples of the form $<\mathrm{x}, \mathrm{t}, \mathrm{w}\rangle$ such that $\mathrm{x}$ is elected at $t$ in $\mathrm{w}$. The upshot is to replace the analysis of hope given by (10) with the one in (11). As in the Appendix, truth and denotation are relativized to an assignment of values to variables $(s)$ and to a context of utterance $\left(c^{*}\right)$; using standard notations, $s\left[w_{i} \square w\right]$ is the assignment which is identical to s, except that it assigns to the variable $w_{i}$ the value $w$. (In my highly simplified 
syntax, world or context variables are written on complementizers, though nothing essential hinges on this.)

(10) John hopes that $w_{w_{i}} \square$ is true $_{\mathrm{s}, \mathrm{c}^{*}}$ iff every world w compatible with John's hope is such that $\square$ is true $\mathrm{s}_{\mathrm{s}[\mathrm{w} i \mathrm{w}], \mathrm{c}^{*}}$

(11) John hopes that ${ }_{<x_{i}, t_{j}, w_{k}>} \square$ is true ${\text { s, } \mathrm{c}^{*}}$ iff every triple $<\mathrm{x}, \mathrm{t}, \mathrm{w}>$ compatible

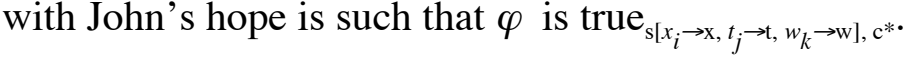

The contrast between (9)a and (9)b can then be derived by positing that (for whatever reasons) PRO must be coindexed with the first coordinate of the triple $<x_{i}, t_{j}, w_{k}>$, while no such requirement holds of $h e$ (e.g. in (12)a $h e_{x_{m}}$ is a free variable which is taken to denote $\mathrm{John}^{5}$ ). For readability I will sometimes replace that with to, without giving any account of the difference; and as is done in the Appendix, time and world arguments of a predicate are explicitly represented as suffixes:

(12) a. John hopes that ${ }_{\left.<x_{i}, t_{j}, w_{k}\right\rangle} h e_{x_{m}}$ be-elected- $t_{j}-w_{k}$ is true $\mathrm{s}_{\mathrm{s} \mathrm{c}^{*}}$ iff for every triple $<\mathrm{x}, \mathrm{t}, \mathrm{w}>$ compatible with John's hope, $\mathrm{s}\left(\mathrm{x}_{\mathrm{m}}\right)$, i.e. John, is elected at $\mathrm{t}$ in $\mathrm{w}$.

b. John hopes $t o_{\left\langle x_{i} t_{j^{*}}, w_{k}\right\rangle} P R O_{x_{i}}$ be-elected-t $t_{j}-w_{k}$ is true $\mathrm{s}_{\mathrm{s}, \mathrm{c}^{*}}$ iff for every triple $<\mathrm{x}, \mathrm{t}, \mathrm{w}>$ compatible with John's hope, $\mathrm{x}$ is elected at $\mathrm{t}$ in $\mathrm{w}$.

This appears to derive the correct truth-conditions. In order to account for the non-standard behavior of the indexicals discussed in (2), we may restate this analysis by observing that a triple of the form $<\mathrm{x}, \mathrm{t}, \mathrm{w}\rangle$ can be identified with a context, i.e. a point at which an act of thought or of speech could originate ${ }^{6}$. Such a re-analysis has the advantage of explaining why certain indexicals that are in the scope of an attitude operator appear to be evaluated with respect to the context of the reported speech act, as was shown in (2). The semantic rule in (11) can then be re-written as in (13)a, and the analysis in (12) can be restated as in (13)b, where $c_{A}$ denotes the author of the context $c, c_{T}$ its time of occurrence and $c_{W}$ its world of occurrence (again, the switch from that to to is for convenience only):

(13) a.John hopes that $c_{c_{1}} \square$ is true ${\mathrm{s}, \mathrm{c}^{*}}$ iff for every context c compatible with John's hope, $\square$ is true $\mathrm{s}_{\left[c_{1}>\mathrm{c}\right], \mathrm{c}^{*}}$ b. John hopes to ${ }_{c_{I}} P R O_{c_{I A}}$ be-elected- $c_{I T^{-}} c_{l W}$ is true ${\mathrm{s}, \mathrm{c}^{*}}$ iff for every

\footnotetext{
${ }^{5}$ If John were replaced with a quantifier or a $\square$-abstractor, $h e_{x_{m}}$ could be bound. Thus to account for the contrast between 'Every candidate hopes to be elected' and 'Every candidate hopes to be elected' we may posit the following logical forms:

(i) a. [Every candidate $]_{x_{m}}\left[t_{x_{m}}\right.$ hopes that $t_{<x_{i}, t_{j}, w_{k}>}>e_{x_{m}}$ be-elected- $\left.t_{j}-w_{k}\right]$

b. [Every candidate $]_{x_{m}}\left[t_{x_{m}}\right.$ hopes to ${ }_{<x_{i}, t_{j}, w_{k}>} P R O_{x_{i}}$ be-elected- $\left.t_{j}-w_{k}\right]$

${ }^{6}$ This is a slight simplification. The identification is possible only if $x$ exist at $t$ in $w$ (if this condition is not met, there is presumably no context that corresponds to $<\mathrm{x}, \mathrm{t}, \mathrm{w}\rangle$ ).
} 
context c compatible with John's hope, the agent of $\mathrm{c}$ is elected at the time of $\mathrm{c}$ in the world of $\mathrm{c}$.

Within this framework, the embedded present tense of the Russian example in (2)a is simply taken to spell-out the term $c_{I T}$, the time coordinate of the embedded context $c_{l}$; while the embedded first person pronoun in the Amharic example in (2)b is the morphological reflex of the author coordinate $c_{1 A}$ of $c_{1}$. The latter case is illustrated in (14), which can be seen to be semantically analogous to (13)b:

(14) John says that $c_{c_{I}} c_{I A}$ be-a-hero- $c_{I T}-c_{I W}$ (Amharic) is true $\mathrm{s}_{\mathrm{s}, \mathrm{c}^{*}}$ iff for every context compatible with John's claim, the agent of $\mathrm{c}$ is a hero at the time of $\mathrm{c}$ in the world of $\mathrm{c}$.

\subsubsection{Sequence of Person Rules}

Whether one adopts the system in (11) or that in (15), the same formal problem arises: even though in a pre-theoretical sense $P R O$ is coreferent with John, the analysis does not establish any formal link between the two. And yet PRO does appear to inherit the features of John, since it can transmit them to a reflexive pronoun that it binds locally, as in (15):

(15) John hopes $\mathrm{PRO}_{\mathrm{i}}$ to buy himself $\mathrm{i}$ a car

Of course one could claim that the masculine features of himself are there because they are semantically interpreted - after all, it is reasonable to presuppose in (15) that the denotation of $P R O$, and thus also of himself, is indeed a male individual. Unfortunately even when this is not the case the sentence remains grammatical, contrary to one's initial expectations (this example is from Schlenker 2002a):

(16) John (a transsexual) hopes PRO to become a woman, and he hopes $\mathrm{PRO}_{\mathrm{i}}$ to buy himself ${ }_{\mathrm{i}}\left({ }^{*}\right.$ herself $\left._{\mathrm{i}}\right)$ a car.

Since attitude verbs are analyzed as structures of universal quantification over contexts, the first conjunct asserts that for every context c compatible with John's hope, the author of $c$ is a woman. But standard rules of presupposition projection applied to the second conjunct lead one to expect that for every context c compatible with John's hope, the author of $c$ should be male (because 'himself' triggers a presupposition that the denotation of PRO should be male). ${ }^{7}$ As a result, (16) as a whole should be incoherent, contrary to fact ${ }^{8}$.

\footnotetext{
${ }^{7}$ This is because in structures of restricted universal quantification presupposition projection requires that every element (in fact, assignment function) that satisfies the restrictor should satisfy the presuppositions of the nuclear scope. For instance in 'Every director admires herself', the expected presupposition is that every director should be female - hence the impression that the speaker is presupposing that every director in the domain of discourse is a woman (this holds only in non-politically correct English). The same reasoning applies to attitude verbs as we analyze them (the role of the restrictor is played by the set of contexts compatible with the agent's attitude).
} 
In sum, within the present framework it cannot be argued that the features of the embedded PRO or of the reflexive 'himself' are semantically licensed. The problem is familiar from the research on De Se readings, and it has lead Heim 1994a to state purely morphological rules of agreement between PRO and the matrix subject. While the agreement rules that are posited by each theory of De Se readings are bound to be somewhat stipulative $^{9}$, it is noteworthy that the problem they are designed to solve has a direct counterpart in the tense literature. Consider the example in (17)a, whose embedded tense is interpreted De Se, i.e. as the time coordinate of the embedded context. One could either posit a logical form as in b. or as in c.:

(17) a. She thought that he (e.g. Clinton) was president (Simultaneous reading, temporal De $\mathrm{Se}$ )

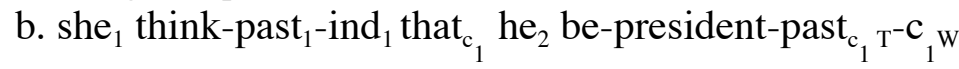

c. she think-past $_{1}$-ind that $_{\mathrm{c}_{1}}$ he be-president-c $_{1} \mathrm{~T}^{-\mathrm{c}_{1} \mathrm{~W}}$

In b. the embedded past tense morpheme is assumed to be visible for semantic interpretation, while in c. it is assumed to be semantically invisible, and thus to be present in the pronunciation only (in the latter case one must explain how a post-syntactic rule may transform $\mathrm{c}_{1}{ }_{\mathrm{T}}$ into a past tense morpheme; this is discussed below). If the past tense features are semantically interpreted, they should contribute a presupposition that $c_{1}{ }_{T}$ denotes a moment prior to the time of the context of utterance $c^{*}$. If so standard rules of presupposition projection would predict the following (slightly simplified) definedness conditions, where the predicate be weird $_{s, c^{*}}$ is used in the meta-language to indicate presupposition failure with respect to an assignment function s and a context of utterance $\mathrm{c}^{*}$ (the conditions are simplified because I only consider cases of presupposition failure that are triggered by the embedded past tense; a more complete treatment is given in the Appendix):

(18) (17)b is weird ${\mathrm{s}, \mathrm{c}^{*}}$ iff ... for some context c compatible with what $\mathrm{s}\left(x_{1}\right)$ believes at time $\mathrm{s}\left(t_{l}\right)$ in world $\mathrm{s}\left(w_{l}\right), \mathrm{c}_{\mathrm{T}}$ is not prior to $\mathrm{c}^{*}{ }_{\mathrm{T}} \ldots$

As has been observed in the literature, this prediction is incorrect. Even if the agent of the attitude thinks that the time of her thought act is after the time at which the sentence is uttered, the grammaticality of our example remains unaffected. This is brought out by the following variation of (17)a (also from Schlenker 2002a):

\footnotetext{
${ }^{8}$ The precise reasoning is as follows: since the first conjunct $\quad$ (16) asserts that all contexts compatible with John's hope are contexts whose agent is a woman, this fact should be a presupposition of the second conjunct. This should suffice to license the feminine features on herself, while himself should be disallowed, contrary to what is observed.

${ }^{9}$ However see Heim 2002 for an attempt to relate these rules to a more general mechanism of feature transmission under binding.
} 
(19) [Uttered in 2002]

In 1999 Mary believed that she was already in year 2005, and she thought that he (e.g. Clinton) was still president

Here the first conjunct asserts (on a temporal De Se reading) that for each context c compatible with Mary's belief, the time of c is after the time of utterance $(=2002)$. But in the second conjunct the past tense of 'was' triggers a presupposition that the time of each context compatible with Mary's belief should be before the time of utterance. This raises an obvious problem for the theory. There are two ways to solve it:

(i) We could deny that such examples involve a De Se reading. In the case of PRO, this option was not open because we had semantic evidence that PRO is not simply read De Re. But to my knowledge no analogous argument has been given in the case of tense. In fact, on anybody's theory it is very hard to see how the past tense could fail to have, among others, a De Re reading. Thus the issue is a particularly subtle one: on the assumption that the embedded tense has a De Re reading, can we find evidence that it also has a De Se reading? An equally difficult problem would have been raised if we had asked whether he, which uncontroversially has a De Re reading, also has a separate De Se reading ${ }^{10}$. The heart of the difficulty is that a De Se reading is standardly assumed to entail the corresponding De Re reading. Thus the task is to argue for the separate existence of a 'strong' reading (the De Se reading), which asymmetrically entails a 'weak' reading (the De Re reading). This is a somewhat nightmarish situation for the semanticist, since any situation compatible with the strong reading will ipso facto be compatible with the weak reading - which leaves open the possibility that only the latter exists (that is, that the 'strong reading' is in fact no reading at all, but just a borderline case of the weak reading; see Fauconnier 1975 and Reinhart 1997 for other instances of the same argumentative situation). The possibility of analyzing part of the data in a De Re fashion is discussed in Section 1.4 below.

(ii) Alternatively, we may posit that the embedded tense is really read De Se, but that its features are invisible in the interpretive component; or to put it differently, that the embedded tense inherits the features of the matrix tense in a purely morphological fashion.

The latter alternative is particularly natural for reasons of symmetry, but also because there are other cases in which a De Re analysis won't do, namely those that were originally taken to argue decisively in favor of rules of purely morphological tense agreement, as in the Kamp \& Rohrer example we cited above:

(20) John decided yesterday that tomorrow he would tell his mother that they were having their last meal together.

\footnotetext{
${ }^{10}$ After I had completed this paper, I learned that O. Percus and U. Sauerland had provided a full argument for the existence of De Se readings of he (see Percus \& Sauerland 2002). It would be interesting to try to apply their methods to tense. I leave this for future research.
} 
No De Re analysis will save us from positing an agreement rule in this case, since on a De Re construal the time of the event denoted by the most embedded verb lies in the speaker's future even though 'were' bears past tense features. The idea, then, is that both (19) and (20) can be accounted for by one and the same rule of morphological agreement, which is in effect the temporal counterpart of the Sequence of Person rule that was posited above. I now mention an argument for positing an analogous rule of mood agreement (Section 1.2), and sketch a unified (and admittedly stipulative) account of agreement phenomena in attitude reports (Section 1.3). A partial alternative in terms of a De Re analysis is sketched in Section 1.4.

\subsection{The Necessity of Rules of Mood Agreement}

Consider the following sentence:

(21) a. She thinks that it is raining.

b. she think-past $_{1}-$ ind $_{1}$ that $\mathrm{c}_{1}$ be-raining- $\mathrm{c}_{1}$-ind $\mathrm{c}_{1} \mathrm{w}$

c. she ${ }_{1}$ think-past ${ }_{1}-$ ind $_{1}$ that ${ }_{\mathrm{c}_{1}}$ be-raining- $\mathrm{c}_{1} \mathrm{~T}^{-} \mathrm{c}_{1} \mathrm{w}$

As was the case in our discussion of embedded tense in (17), two analyses suggest themselves. According to the representation in (17)b, the indicative features of the embedded clause are interpreted, and thus introduce a certain presupposition on the value of the term $\mathrm{c}_{1} \mathrm{w}$. By contrast, in the representation given in (21)c the embedded indicative features are assumed to be semantically invisible, and thus to trigger no presupposition at all.

While the semantic analysis of the indicative is controversial, it would appear that the representation in (21)b will systematically lead to incorrect predictions.

(i) Suppose first that a world-denoting term with indicative features is presupposed to denote the world of utterance. Then a problem appears immediately, since for (21)a this leads to the prediction that the world of every context compatible with the agent's beliefs should be the actual world. Since this means that the agent must have perfect and complete knowledge of the world, the analysis is clearly undesirable.

(ii) Suppose now that a more elaborate theory of the indicative is adopted, along the lines of Stalnaker 1975. In the terms of the present discussion, Stalnaker essentially assumed that an indicative feature introduces a presupposition that the world-denoting term on which it appears denotes one of the worlds compatible with what the speech act participants presuppose (i.e. one of the worlds in the set $\left\{\mathrm{c}_{\mathrm{w}}\right.$ : $\mathrm{c}$ is compatible with the participants of $\mathrm{c}^{*}$ presuppose at time $\mathrm{c}^{*}{ }_{\mathrm{w}}$ in world $\left.\mathrm{c}^{*}{ }_{\mathrm{w}}\right\}$; this is what Stalnaker calls the 'context set ${ }^{11}$ ). The theory was designed to account for indicative conditionals, such as 'If John comes, Mary will be happy'. On a common theory of

\footnotetext{
${ }^{11}$ The terminology is unfortunate since for us the 'context set' is really a set of possible worlds (Stalnaker 1968, 1975 was not concerned with the world/context distinction).
} 
conditionals (developed in Stalnaker 1968), the if-clause denotes the closest world from the world of utterance in which John comes; and the entire sentence is true just in case that world, call it w, is one in which Mary is happy. In this framework the contribution of the indicative mood is to trigger a presupposition that $\mathrm{w}$ is compatible with what the speech act participants presuppose, and thus that it is possible that John will come. While such a theory has desirable consequences for the analysis of conditionals, it leads to incorrect predictions for (21)b. If we apply once again rules of presupposition projection in universally quantified structures, we obtain the requirement that for every context $c$ compatible with the agent's belief, the world of $c$ is compatible with what the speech act participants presuppose. In other words, the worlds compatible with the agent's beliefs are presupposed to be also compatible with the beliefs of the speech act participants. But this is incorrect: no matter how outlandish the agent's beliefs may appear to the speaker and hearer, the grammaticality of (21)b will remain unaffected. ${ }^{12}$

The obvious solution, then, is to suppose that there are purely morphological rules of agreement in attitude reports, so that the indicative features of the embedded verb in (21)a are semantically invisible, in line with the hypothesis in (21)b.

\subsection{Analysis}

If the foregoing observations are correct, some rules of morphological agreement are needed to handle person, tense and mood when these appear in the scope of an attitude verb. More precisely, terms of the form $\mathrm{c}_{\mathrm{i}} \mathrm{A}, \mathrm{c}_{\mathrm{i}}$ or $\mathrm{c}_{\mathrm{i}} \mathrm{W}$ (the author, time and world coordinates of a context $c_{i}$ ) are pronounced with features that are inherited from an argument of the attitude verb and are not semantically interpreted. Why such a phenomenon should exist in the first place is a complete mystery; our attempt will only be to state a stipulation that accounts for the similarity between person, tense and mood agreement.

The idea we pursue is that the formation rule of attitude operators requires that the context variables (in our implementation: the

12 In principle the same point could also be made about subjunctive conditionals, but the difficulty is that there is no consensus on how these should be analyzed semantically [one possible theory is that the subjunctive does not introduce any special semantic constraint, and that its contribution is purely pragmatic, arising from an implicature that the speaker could not have marked the conditional as indicative; see von Fintel 1997 for a related theory]. In any event, it also appears that whatever semantic/pragmatic contribution a subjunctive mood normally makes disappears when it can be analyzed as the result of agreement with a superordinate attitude verb. Thus a. below presents Mary's act of thinking as possible, while in b. there is a presumption that it is counterfactual; but there is not corresponding difference between the way the event of raining is presented in a. and in b. On the present analysis this is because the modal features of be raining in a. and b. result from a rule of morphological agreement with the super-ordinate attitude verb; as a result, these features need not be present in the interpretive component and thus have no semantic consequences.

(ii) a. If she thinks that it is raining, she will take an umbrella

b. $<>$ If she thought that it was/were raining, she would take an umbrella 
complementizers) inherit the features of the individual, time and world arguments of the embedding verb. These features are then pronounced in a post-syntactic (morphological) component of the grammar (what syntacticians call 'PF'). A full fragment is developed in the Appendix, but the crucial definition is given below:

(22) If $\square$ is a formula, $\mathrm{P}$ is an attitude verb, $\mathrm{i}$ is an individual term, $\mathrm{t}$ is a time term, $\mathrm{w}$ is a world term, and $\mathrm{k}$ is an integer, then $i P-t-w t t_{c_{k^{F}}} \square$ is a formula, where $\mathrm{F}$ is the triple of $\{\mathrm{e}, h e$, she $\} \square\{\mathrm{e}$, pres, past $\} \square\{\mathrm{e}$, ind , subj\} whose first coordinate is he/she if he/she appears in i, and e otherwise; whose second coordinate is pres/past if pres/past appears in $\mathrm{t}$, and e otherwise; and whose third coordinate is ind/subj if ind/subj appears in $\mathrm{w}$, and e otherwise.

The bulk of the morphological work is played by the triple of features $\mathrm{F}$, which plays no semantic role. In the phonological component, each coordinate of a context, of the form $c_{i A}^{F}, c_{i T}^{F}, c_{i W}^{F}$ is replaced with the corresponding coordinate of $F$. This is illustrated in the following example, where each argument (individual, time and world) of the embedded verb is read De Se, i.e. spells out a coordinate of the embedded context.

(23) a. He hopes that he is elected (De Se Reading for the embedded he)

b. he hope-pres $_{1}-$ ind $_{1}$ that $\mathrm{c}_{\mathrm{c}_{1} \mathrm{~F}} \mathrm{c}_{1}^{\mathrm{F}}{ }_{\mathrm{A}}^{\mathrm{F}}$ be-elected $-\mathrm{c}_{1}^{\mathrm{F}} \mathrm{T}^{-} \mathrm{c}_{1}{ }_{\mathrm{W}}^{\mathrm{F}}$, with $\mathrm{F}=<$ he, pres, ind $>$

c. (b) is pronounced as: he hope-pres-ind that he be-elected-pres-ind

(23)a receives the syntactic analysis in (23)b, which serves both as an 'Sstructure' and as a 'Logical Form'. In the phonological component the sentence is pronounced as in (23)c, where $c_{1}^{F}{ }_{A}, c_{1}{ }_{T}$ and $c_{1}^{F}{ }_{W}$ have been replaced with he, pres and ind respectively, as is desired. Finally the truth-conditions are the ones that one would expect: when the sentence does not result in a presupposition failure (as is for instance the case when the matrix argument $h e_{1}$ is used with the intention of referring to a female individual), it is true just in case for every context compatible $\mathrm{c}$ with the agent's hope (at the time and world of the utterance $\left.\mathrm{c}^{*}\right)$, the author of $\mathrm{c}$ is elected at the time of $\mathrm{c}$ in the world of c.

Let us observe that something special must be said about future auxiliaries. For an attitude verb in the future triggers the same agreement behavior as if it were in the present. In particular, the future tense features are not morphologically transmitted to the embedded verb, so that for instance 'John will say that he will be elected' does not readily have a reading on which John's utterance is supposed to be of the form: 'I am elected' (rather, the sentence is naturally understood as predicting that John will say: 'I will be elected', which shows that the embedded future tense features are semantically interpreted). Similarly, an attitude verb preceded by would (analyzed as the past tense of will, i.e. will-ed) triggers the same agreement as would be found 
under an attitude verb in the past tense. In order to capture these facts, I posit that the future is always composed of two parts: will is analyzed as will(pres), while would is analyzed as will(past) ${ }^{13}$. In line with the analysis of tenses as variables, I assume that both parts of the compound come equipped with their own referential indices. I further assume that the argument of will (whether it is pres or past) only has the power to trigger a presupposition failure. For instance will $_{i}\left(\right.$ past $\left._{k}\right)$ yields a presupposition failure under an assignment $\mathrm{s}$ in a context $\mathrm{c}^{*}$ (i.e. it denotes ${\mathrm{s}, \mathrm{c}^{*}} \#$ ) in case $\mathrm{s}\left(t_{i}\right)$ (so to speak, the denotation of will) is not after $\mathrm{s}\left(t_{k}\right)$ (=the denotation of the past tense). But in case no presupposition failure occurs, the argument of will plays no additional role, so that for instance will $_{i}\left(\right.$ past $\left._{k}\right)$ simply denotes ${ }_{\mathrm{s}, \mathrm{c}^{*}} \mathrm{~s}\left(t_{i}\right)$. On the morphological side, I assume that the features of will never appear on the diacritics of context variables, but that the features of pres and past do get so transmitted. This provides an account of Kamp \& Rohrer's example, along the following lines:

(24) a. He decided (yesterday) that (tomorrow) he would say (to his mother) that he was leaving (the embedded past tenses need not be interpreted)

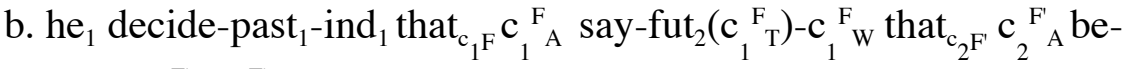
leaving- $\mathrm{C}_{2} \mathrm{~F}^{\prime} \mathrm{T}^{\prime}-\mathrm{C}_{2} \mathrm{~F}^{\prime} \mathrm{W}$ with $\mathrm{F}=\mathrm{F}^{\prime}=<$ he, past, ind $>$ c. (b) is pronounced as: he decide-past-ind thathe say-fut(past)-ind that he be-leaving-past-ind

Each argument of the first embedded verb (say) is a coordinate of the context variable $c_{1}$, which bears the diacritic $\mathrm{F}=<$ he, past, ind $>$ because the arguments of the embedding verb (decide) are $h e_{1}$, past $_{1}$ and $i n d_{l}$. As a result, $c_{1}{ }^{F}$, fut $t_{2}\left(c_{1}{ }_{T}\right)$ and $c_{1}{ }^{F}$ are eventually pronounced as he, fut-past (i.e. would) and ind respectively. But this is not the end of the story. The features that appear on $c_{1}{ }_{A}, f u t_{2}\left(c_{1}{ }_{T}\right)$ and $c_{1}{ }_{W}$ are then copied onto the diacritic $F^{\prime}$ of the context variable $c_{2}$, in accordance with the rule stated in (22). The rule requires that $\mathrm{F}^{\prime}$ should have as its first coordinate the person features that appear in $c_{1}{ }_{A}$, that is, he (since $\mathrm{F}=<$ he, past, ind $>$ ). Similarly the second coordinate of $\mathrm{F}^{\prime}$ should include the tense features of $f u t_{2}\left(c_{1}{ }_{T}\right)$, excluding fut (which does not enter in agreement phenomena); this simply yields past. And by the same token the third coordinate of $\mathrm{F}^{\prime}$ should be ind, so that in the end $\mathrm{F}^{\prime}=<$ he, past, ind $>$ ends up being identical to F. $c_{2}^{F^{\prime}}$ can then trigger the correct agreement patterns on the individual, time and world arguments of the most deeply embedded verb,

\footnotetext{
${ }^{13}$ By no means does this suffice to account for the full behavior of the future. One basic phenomenon which is left out of the present discussion is the ability of a future operator to shift the point of evaluation of a present tense which is in its scope, as in the following example:
}

(iii) John will meet a man who is holding a copy of L\&P in his hand (Ogihara 1996 p. 161) 
which are all coordinates of $c_{2}^{F^{\prime}}$, and are thus pronounced as he, past and ind respectively.

\subsection{An alternative without person and mood agreement but with (some) tense agreement}

One major drawback of this system is that it relies on agreement rules that are entirely ad hoc. Its major virtue is that the agreement rules are uniform across referential domains, in the sense that a single rule takes care of person, tense and mood agreement all at once. One way to improve on this system would be to motivate the rule in question, for instance by showing that it falls under a broader system of agreement between a variable and its binder. This has been attempted in Heim 2002, although many stipulations are admittedly needed to make attitude verbs fall in line with generalized quantifiers ${ }^{14}$.

An alternative would be to deny that an agreement rule is necessary to begin with. The suggestion builds on the observation that a De Se reading entails the corresponding De Re reading; in other words, if it is true that John hopes to be elected, it is also true that John hopes, of John, that he will be elected. As a result, a De Se reading can be analyzed as a De Re reading that has certain additional requirements. In this fashion we can do without agreement in most, though not in all cases. A tense agreement rule remains necessary to account for Kamp \& Rohrer's example, as was pointed out above.

Let us first consider the issue of Quantifying In independently of the De Se problem. The initial observation, due to Quine 1956, was that both of the following sentences may simultaneously be true:

(25) a. Ralph believes, of Ortcutt, that he is a spy (qua the man Ralph saw at the cocktail party)

b. Ralph believes, of Ortcutt, that he is not a spy (qua the man Ralph saw at the beach).

On the assumption that beliefs are closed under conjunction, the simplest analysis would risk attributing irrationality to Ralph. For instance if we analyze (25)a as asserting that every world (resp. every context) compatible with Ralph's belief is one in which Ortcutt is a spy, by parity of reasoning we will also have to analyze (25)b as asserting that every world (resp. every context) compatible with Ralph's belief is one in which Ortcutt is not a spy. Since there are no worlds in which Ortcutt both is and isn't a spy, there should be no worlds at all (resp. no contexts at all) compatible with Ralph's beliefs, which should make him irrational. This fails to distinguish irrationality from cases of mistaken identity. Kaplan's solution in 'Quantifying In' was to

\footnotetext{
${ }^{14}$ Heim's observation was that in, say, [Only I] $\square x x$ did $m y_{x}$ homework, the first person possessive pronoun $m y_{x}$ must be allowed to range over non-speakers. This suggests that its features are the result of agreement with the generalized quantifier [Only I], which is itself presumed to inherit the features of $I$. Heim's attempt is to re-analyze the syntax of attitude verbs in order to make them fall under the same kind of agreement rules. I refer the reader to Heim 2002 for details.
} 
reintroduce in his truth-conditions the mode of presentation under which Ralph held the relevant beliefs. According to Kaplan, what is asserted by (25)a is that for some 'vivid' description $\square$ which in fact picks out Ortcutt, Ralph believes (De Dicto): $\square$ is a spy (for instance $\square$ may be the description the man I saw at the cocktail party). This doesn't exclude that for some other description $\square$ ' that also denotes Ortcutt (e.g. the man I saw at the beach) Ralph may believe: $\square$ ' is not a spy. As long as $\square$ and $\square$ ' are different, no irrationality need be attributed to Ralph, just as we desired.

Crucially, not any description that happens to pick out Ortcutt will count as 'vivid'. For instance Ralph would certainly assent to: 'The shortest spy is a spy'; and it might well be that (unbeknownst to Ralph) the description 'the shortest spy' does in fact pick out Ortcutt. Still, one wouldn't say in this situation that 'Ralph believes that Ortcutt is a spy'. Somehow for the De Re reading to be true Ralph must bear some direct connection to Ortcutt. This is what motivates Kaplan 1969 to add the restriction that the description should be 'vivid'. How 'vivid' should be defined is an open question; but it is clear that some restriction of this kind is needed for De Re readings of individualdenoting terms. As will become clear later, an analogous restriction is necessary in the analysis De Re readings of time- and world-denoting terms, as one would expect.

Abusch 1997 adopts a variant of Kaplan's theory in which there is no existential quantification over vivid descriptions. Rather, she assumes that the relevant (vivid) description is contextually given. One motivation for doing so is that (25)a and (25)b cannot both be asserted in a given context. Arguably, 'Ralph believes that Ortcutt is a spy, and he also believes that Orctutt is not a spy' sounds like a near-contradiction, contrary to what Kaplan would predict. Abusch's variant can explain this on the assumption that only one 'vivid' description of Ortcutt can be salient in a given context. (25)a and (25)b can still both be true, but they cannot both be asserted felicitously in the same context. Without taking a principled stance on this issue, I adopt this modified version of Kaplan's analysis, mainly because it simplifies the formal development of the system.

At this point any theory is bound to make somewhat stipulative assumptions to derive the correct truth-conditions. On the approach pursued in Abusch 1997 and Heim 1994b, the De Re term is moved outside of the embedded clause by an operation of covert movement. There is no syntactic evidence for such an operation, which would have to violate standard island constraints on movement ${ }^{15}$. On the other hand it allows the semantics to

\footnotetext{
${ }^{15}$ Consider the following:

(iv) [Talking to Ortcutt] Ralph believes that if you are a spy, you must have caused a lot of trouble.

Here you must be quantified in. On the movement approaches mentioned above, you would have to be raised out of the if-clause to become an argument of believe. This is not a satisfactory analysis, since it is known that if-clauses are islands to movement.
} 
operate relatively smoothly, in a compositional fashion. Here I have adopted a different method, which is to stipulate that each free variable ranging over objects of sort $\mathrm{S}$ in the scope of an attitude operator is replaced with a variable over functions from contexts to objects of sort $S$ (i.e. descriptions of objects of sort S), indexed with the closest c-commanding context variable:

(26) If $\mathrm{k}$ is the index of a free variable in the immediate scope of an attitude verb introducing a variable $\mathrm{c}_{\mathrm{i}}^{\mathrm{F}}$, replace $\mathrm{k}$ with $\mathrm{k}^{*}, \mathrm{i}$.

For example, a variable $\mathrm{x}_{2}$ in the immediate scope of an attitude verb introducing a variable $c_{1}{ }^{F}$ is replaced with the expression $x_{2^{*}, 1}$. Its value under an assignment $\mathrm{s}$ is $\mathrm{s}\left(x_{2^{*}}\right)$, a function from contexts to individuals, applied to $\mathrm{s}\left(c_{1}\right)$. This yields the individual named or described by $\mathrm{s}\left(x_{2^{*}}\right)$ in the context $\mathrm{s}\left(c_{1}\right)$, as is desired. (In Quine's example, $\mathrm{s}\left(x_{2^{*}}\right)$ might be the value of the description 'the man I saw at the beach', or of 'the man I saw at the cocktail party'). Here is an illustration:

(27) a. He thought that she was pregnant (De Re for the embedded she, De Se for the embedded past tense)

b. he think-past $_{1}-$ ind $_{1}$ that $_{\mathrm{c}_{1} \mathrm{~F}}$ she $_{2}$ be-pregnant-c ${ }_{1}{ }_{\mathrm{T}}-\mathrm{c}_{1}{ }_{\mathrm{W}}^{\mathrm{F}}$, with $\mathrm{F}=<$ he, past, ind >

c. he think-past $_{1}-$ ind $_{1}$ that $_{\mathrm{c}_{1}^{\mathrm{F}}}$ she $_{2^{*}, 1}$ be-pregnant-c $\mathrm{c}_{1}^{\mathrm{F}}-\mathrm{c}_{1}^{\mathrm{F}}{ }_{\mathrm{W}}$, with $\mathrm{F}=<$ he, past, ind >

d. When (c) is not weird $\mathrm{s}_{\mathrm{s}, \mathrm{c}^{*}},(\mathrm{c})$ is true ${\mathrm{s}, \mathrm{c}^{*}}^{*}$ iff for every context $\mathrm{c}^{\prime}$ in think $^{<\left(x_{I}\right), \mathrm{s}(t), \mathrm{s}\left(w_{1}\right)>}, \mathrm{s}\left(x_{2^{*}}\right)\left(\mathrm{c}^{\prime}\right)$ is pregnant at the time $\mathrm{c}_{\mathrm{T}}^{\prime}$ in the world $\mathrm{c}_{\mathrm{W}}^{\prime}$.

e. Pronunciation: he think-past-ind that she be-pregnant-was-ind

(27)b is the formula generated by the initial version of the system, without De Re transformation. (27)c is the output of the De Re transformation, which only affects the pronoun $s h e_{2}$, transformed into $s h e_{2^{*}, 1}$, which could have been written less concisely as $s h e_{2 *}\left(c_{1}^{F}\right)$. The pronunciation is, of course, as in the old system. As for the truth-conditions, they are given in simplified form in (27)d, where the various possible sources of presupposition failure have been omitted.

This system can then be modified to account for De Se readings, treated as a species of De Re readings in which the only acceptable descriptions are $I$ (for individuals), now (for times) and actually (for worlds). In Appendix C this idea is implemented by optionally substituting ' + ' to '*' after the De Re Transformation, with the convention that in such cases the corresponding description is presupposed to be restricted to the value of $I$, now or actually (i.e. $\square \mathrm{c}_{\mathrm{A}}, \square \mathrm{c}_{\mathrm{T}}$ or $\square \mathrm{c} \mathrm{c}_{\mathrm{W}}$ ). One example (developed in Appendix $\mathrm{C}$ ) is given in simplified form in (28), where each of the embedded arguments is read De Re and De Se. The important observation is that this is achieved without recourse to any of the terms $\mathrm{c}_{1}^{\mathrm{F}}{ }_{\mathrm{A}} \mathrm{C}_{1}^{\mathrm{F}}, \mathrm{C}_{1}^{\mathrm{F}}$, which were used above to derive De Se 
readings; and that therefore the diacritic F plays no role in deriving the correct pronunciation.

(28) a. He hopes that he is elected / He hopes that he himself is elected / He hopes to be elected (De Se Reading for each of the embedded arguments)

b. he think-pres $_{1}-$ ind $_{1}$ that $_{\mathrm{c}_{1} \mathrm{~F}}$ he $_{1}$ be-elected-pres -ind $_{1}$, with $\mathrm{F}=<$ he, pres, ind>

c. he think-past $_{1}$-ind that $_{\mathrm{c}_{1} \mathrm{~F}}$ he $_{1+, 1}$ be-elected-pres ${ }_{1+, 1}$-ind $_{1+, 1}$, with

$\mathrm{F}=<\mathrm{he}$, past, ind $>$

$\mathrm{d}$. When (c) is not weird ${\mathrm{s}, \mathrm{c}^{*},},(\mathrm{c})$ is true ${\mathrm{s}, \mathrm{c}^{*}}$ iff for every context $\mathrm{c}^{\prime}$ in think $^{<\mathrm{s}\left(x_{l}\right), \mathrm{s}(t), \mathrm{s}\left(w_{I}\right)>}, \mathrm{s}\left(x_{l_{+}}\right)\left(\mathrm{c}^{\prime}\right)$ is elected at time $\mathrm{s}\left(t_{l_{+}}\right)\left(\mathrm{c}^{\prime}\right)$ in world $\mathrm{s}\left(w_{1+}\right)\left(\mathrm{c}^{\prime}\right)$, i.e. $\mathrm{c}_{\mathrm{A}}^{\prime}$ is elected at time $\mathrm{c}_{\mathrm{T}}^{\prime}$ in world $\mathrm{c}_{\mathrm{W}}^{\prime}$.

e. Pronunciation: he think-past-ind that he be-elected-pres-ind

This system can be extended to tense and mood (see Appendix C). However it cannot account for Kamp \& Rohrer's example, since there is no sense in which the tense of the most deeply embedded verb (was leaving) can be interpreted as being De Re with respect to any past moment. For this example we are thus forced to posit a Sequence of Tense rule, one that does not appear to have any counterpart in the person or in the mood domain. Thus it is unclear that any net gain is obtained by giving a De Re treatment of De Se readings; although the need for a mechanism of morphological agreement is obviated in some cases, some stipulations remain necessary for the original Sequence of Tense cases.

\section{Double Access Readings with Tense and Mood: the Generalized Upper Limit Constraint}

If the approach developed in Sections 1.1-1.3 is on the right track, the phenomenon of Sequence of Tense in English should be analyzed as one instance of a more general agreement mechanism that affects in the same fashion person, tense and mood. There is, however, another phenomenon that has been taken to target specifically tense in attitude reports: the existence of so-called 'Double Access Readings'. In this section I suggest that the equivalent of Double Access Readings exists with mood, and I try to generalize the theory of Abusch 1997 to account for this phenomenon. As was the case in Section 1, the goal is not to derive the facts from first principles, but only to show that some stipulations that have been taken to apply specifically to tense can be stated in a slightly more general fashion so as to account for similar phenomena in the domain of mood. (Person is left out of the present discussion, since to my knowledge it does not display the equivalent of Double Access Readings). 


\subsection{The Generalization}

The initial observation concerning tense is summarized in the following paradigm:

(29) a. \#He already thought ten years ago that she is pregnant ${ }^{16}$.

b. He already thought ten days ago that she is pregnant.

a'. He already thought ten years ago that she would (now) be pregnant.

b'. He already thought ten days ago that she would (now) be pregnant.

a". He thought ten years ago that she was pregnant.

b". He thought ten days ago that she was pregnant.

Unsurprisingly, (29)a" and (29)b" attribute to the agent a thought about the time of his thought act (or according to the De Se analysis sketched above, about the time that he thinks is the time of his thought act); just as unsurprising are (29)a' and (29)b', which (with the adverb now) attribute to the agent a thought about the time of utterance. On the other hand the contrast between (29)a and (29)b is surprising. Abusch 1997 suggests that in this case the present tense serves to attribute to the agent a thought about an interval that includes both the time (that he thinks is the time) of his thought act and the time of utterance (see also Ogihara 2000 for a somewhat different analysis). Surprising though it is, this description accounts for the contrast between (29)a and (29)b, since it would seem that it is difficult for anyone to think that a pregnancy could span an interval of ten years. The point can be made more sharply by considering embeddings under attitude verbs that are factive, and thus force the embedded clause to be true:

(30) a. \#He learned ten years ago that she is pregnant.

b. He learned ten days ago that she is pregnant.

In (30)a the speaker must presuppose that the pregnancy actually spanned ten years, hence the deviance of the sentence given standard assumptions.

The suggestion we wish to pursue is that Double Access Readings also exist under structurally similar conditions in the domain of mood. In such cases the attitude holder must have a thought that is both about the world of the speaker and the world (that he thinks is the world of) his thought act. Particularly striking (though not necessarily robust) is the effect found with factive attitude verbs embedded in the antecedent of a subjunctive conditional:

(31) a. If John learned that Mary was/were (now) pregnant, he would be devastated.

b. If John learned that Mary is (now) pregnant, he would be devastated.

For some speakers (31)b presupposes that Mary is actually pregnant, while no such presupposition holds in (31)a. Furthermore in (31)b the presupposition is

\footnotetext{
${ }^{16}$ As J. Lecarme (p.c.) observes, the sentence becomes acceptable if I report a male individual's thoughts about Mona Lisa. Of course this only confirms the generalization we develop below: thanks to Leonardo, if Mona Lisa is pregnant, she is pregnant in all eternity. And hence her pregnancy does span more than 9 months...
} 
that Mary is pregnant both in the actual world and in the world picked out by the if-clause. Similar facts appear to hold of the French sentences in (32), where the present/past morphology in the antecedent of the conditional is interpreted in a purely modal fashion (both sentences are understood to be about the time of utterance):

(32) a. Si d'aventure Jean apprenait que Marie était enceinte, il serait désespéré. If by adventure Jean learned that Marie was pregnant, he would-be devastated 'If Jean ever learned that Marie was pregnant, he would be devastated' b. Si d'aventure Jean apprenait que Marie est enceinte, il serait déspespéré. If by adventure Jean learned that Marie is pregnant, he would-be devastated 'If Jean ever learned that Marie is pregnant, he would be devastated'.

(32)a only presupposes that Marie is pregnant in the world picked out by the if-clause, so to speak. By contrast (32)b presupposes both that Marie is pregnant in the actual world and in the world picked out by the if-clause. The same effect can to some extent be replicated with a morphological subjunctive in French:

(33) a. Je crains qu'un jour Jean rentre chez lui et qu'il apprenne que Ifear that one day Jean comes-back home and that he learn-subj that Marie soit enceinte.

Marie is-subj. pregnant

b. Je crains qu'un jour Jean rentre chez lui et qu'il apprenne que I fear that one day Jean comes-back home and that he learn-subj that Marie est enceinte.

Marie is-ind. pregnant

There appears to be a preference for interpreting (33)b with a presupposition that Marie is pregnant both in the actual world and in the worlds compatible with what I fear. By contrast (33)a only requires that Marie be pregnant in the worlds compatible with what I fear.

Although these facts are suggestive, they are not entirely robust, and they are also difficult to analyze because of their interaction with the complex issue of presupposition projection in subjunctive conditionals (see for instance Heim 1992 for a treatment). We henceforth concentrate on non-factive attitude verbs, whose behavior is illustrated by the following paradigm:

(34) Situation: It is raining outside.

a. Si Jean pensait qu'il fait beau, il serait fou.

If Jean thought that it did beautiful, he would be crazy

'If Jean thought that the weather was nice, he would be crazy'

b. \#Si Jean pensait qu'il faisait beau, il serait fou.

If Jean thought that it does beautiful, he would be crazy

'If Jean thought that the weather was nice, he would be crazy'

c. Si Jean pensait qu'il faisait beau, il se mettrait en short

If Jean thought that it does beautiful, he SE would-put in shorts

'If Jean thought that the weather was nice, he would put on his shorts' 
Given a situation where both the speaker and the hearer know that is raining, the sentence in (34)a appears to be true. This can be explained in the following way: the if-clause picks out a world $w$ in which Jean thinks, of $w$ and of the actual world $\mathrm{c}^{*}{ }_{\mathrm{w}}$, that they are worlds in which the weather is nice. This thought is not reasonable in view of the evidence available to the speaker and hearer. By contrast, it is hard to make sense of the sentence in (34)b, where Jean's thought in the counterfactual world $\mathrm{w}$ is only about $\mathrm{w}$, not about the world of utterance $\mathrm{c}^{*}{ }_{\mathrm{w}}$. Presumably the closest world from $\mathrm{c}^{*}{ }_{\mathrm{w}}$ in which Jean thinks that the weather is nice need not be a world in which it is raining (as is the case in the actual world), unless Jean is assumed to be systematically misguided in his judgments. Hence (34)b does not sound true or even coherent. As is expected, the incoherence stems from this particular choice of consequence clause; as soon as the latter is modified, as in (34)c, coherence is regained. Similar facts can be replicated in English, although my informant preferred 'claim' to 'think' (again every verb is interpreted as being about the time of utterance; for reasons that I do not understand my informant preferred 'was nice' to 'were nice' in (35)a, and found it helpful to have 'were to claim' rather than 'claim' in the antecedent):

(35) Situation: It is raining outside.

a. If John were to claim that the weather is nice, he would be crazy

b. ??If John were to claim that the weather was nice, he would be crazy

c. <If John were to claim that the weather was nice, Peter would immediately put on his shorts>

In the preceding example the 'counterfactual' mood of the conditional is morphologically expressed with a past tense (imperfect), something which is common across languages (see Iatridou 2000). Lest the reader think that the phenomenon of Double Access Readings is somehow related to tense morphology, I also give a French example in which this is clearly not so (I note, however, that some French speakers appear not accept mood agreement under the subjunctive; for those speakers (36)b is ungrammatical):

(36) Situation: It is raining outside.

a. Il faudrait que Jean prétende qu'il fait beau.

It would-be-necessary that Jean claim-subj. that it does-ind. beautiful

'Jean should claim that the weather is nice'

b. Il faudrait que Jean prétende qu'il fasse beau.

It would-be-necessary that Jean claim-subj. that it does-subj. beautiful

'Jean should claim that the weather was nice'

In (36)a the speaker presents as desirable a situation in which Jean makes a particularly implausible claim, one that entails that the weather in the actual world is in fact nice. No such inference can be drawn from (36)b, even in the situation as described. In other words, the presence of the indicative in the embedded clause triggers an interpretation on which Jean's claim is both about 
the actual world and about the world of his utterance, as is expected on the present analysis.

\subsection{Extending Abusch's Account: the Generalized Upper Limit Constraint}

We now extend to mood the theory of Double Access Readings developed in Abusch 1997. Abusch's analysis of tense is first restated within the present framework, and it is then extended to mood.

\subsubsection{A restatement of Abusch's analysis of Double Access Readings}

One of the important insights in Abusch 1997 was that the existence of Double Access Readings is related to another peculiarity of tense, the unavailability of Forward Shifted Readings in the absence of a future tense morpheme in the embedded clause, as shown below:

(37) a. \#He thought in 1990 that she was pregnant in 2000.

b. He thought in 1990 that she would be pregnant in 2000 .

Following Abusch 1997, the generalization appears to be that the time coordinate of a context variable $\mathrm{c}$ is an 'upper limit' for the denotation of all time terms which are in its immediate scope, in the sense that these may not denote an interval which is entirely after the time of c. Within the framework we develop in the Appendix, we stipulate that a presupposition failure occurs if a time description denotes an interval which is entirely after the denotation of the time coordinate of the closest c-commanding context. The relevant part of the statement is given in (38); it has the effect of preventing time descriptions that correspond to a present or past tense from denoting an interval that lies entirely after the time of the local context:

$$
\begin{aligned}
& \square_{k^{*}, i} \text { denotes }_{\mathrm{s}, \mathrm{c}^{*}} \# \text { iff ...(iii) }[\amalg \text { \{pres, past }\} \text { and } \mathrm{s}\left(t_{k^{*}}\right)\left(\mathrm{s}\left(c_{i}\right)\right) \text { is entirely } \\
& \text { after } \left.\left(\mathrm{s}\left(c_{i}\right)\right)_{\mathrm{T}}\right] \ldots
\end{aligned}
$$

For instance, past $_{k^{*}, i_{i}}$ will denote \#, i.e. trigger a presupposition failure, if the salient description of times $t_{k^{*}}$ fails to denote (in the context $\mathrm{s}\left(c_{i}\right)$ ) an interval that lies entirely after the time of $\mathrm{s}\left(c_{i}\right)$ (remember that given our conventions the second index of past $_{k^{*}, i}$ is the index of the local context variable).

Independently of these unexciting details of implementation, the important observation made by Abusch was that this stipulation (mainly motivated by the unavailability of Forward Shifted Readings) suffices to account for Double Access Readings. Why? Because the Upper Limit Constraint authorizes a time description embedded under a context variable $\mathrm{c}$ to denote an interval $\mathrm{T}$ that reaches beyond the time of $\mathrm{c}$, but only if $\mathrm{T}$ also includes the time of $\mathrm{c}$ - hence the 'Double Access' effect, which attributes to the agent a thought about an interval that has two anchors, so to speak.

Let us see in greater detail how this works. Here is a representative example: 
(39) a. He thought that she is pregnant

b. he think-past $_{1}-$ ind $_{1}$ that $_{\mathrm{c}_{1} \mathrm{~F}}$ she $_{2}$ be-pregnant-pres $2-\mathrm{c}_{1}{ }_{\mathrm{w}}^{\mathrm{F}}$, with $\mathrm{F}=<$ he, past, ind $>$

c. he think-past $_{1}$-ind $_{1}$ that $_{\mathrm{c}_{1} \mathrm{~F}}$ she $_{2^{*}, 1}$ be-pregnant-pres $2_{2^{*}, 1}-\mathrm{c}_{1}{ }_{\mathrm{W}}^{\mathrm{F}}$, with

$\mathrm{F}=<$ he, past, ind $>$

d. (c) is weird ${\text { s, } \mathrm{c}^{*}}^{*}$ iff ... for some $\mathrm{c}^{\prime}$ in $\operatorname{think}^{<\mathrm{s}\left(x_{I}\right), \mathrm{s}(t), \mathrm{s}\left(w_{I}\right)>} \ldots$

(i') $\mathrm{s}\left(t_{2}\right)$ is not $\mathrm{c}_{\mathrm{T}}^{*}$, or

(ii') there is a context c corresponding to $<\mathrm{s}\left(x_{1}\right)$,

$\mathrm{s}\left(t_{1}\right), \mathrm{s}\left(w_{1}\right)>$ and $\left[\mathrm{s}\left(t_{2^{*}}\right)\right.$ isn't vivid for c or $\mathrm{s}\left(t_{2}\right)$ is not a part of $\left.\mathrm{s}\left(t_{2^{*}}\right)(\mathrm{c})\right]$, or

(iii') $\mathrm{s}\left(t_{2^{*}}\right)\left(\mathrm{c}^{\prime}\right)$ is entirely after $\mathrm{c}_{\mathrm{T}}^{\prime} \ldots$

e. Pronunciation: he think-past-ind that she be-pregnant-pres-ind

(39)c is the result obtained after the De Re Transformation, which replaced the time variable pres $_{2}$ with the time description pres $_{2 *, 1}$, whose context argument is $\mathrm{c}_{1}$ (as is indicated by the second subscript of $\operatorname{pres}_{2 *, 1}$ ). Some of the failure conditions are given in (39)d, where it is seen that in the context of the agent's thought act (which we call $c$ ) $\mathrm{s}\left(t_{2^{*}}\right)$ must denote an interval that includes $\mathrm{s}\left(t_{2}\right)$, i.e. (by (i')) the time of utterance $\mathrm{c}^{*} \mathrm{~T}$. But it is also the case that for each context $\mathrm{c}^{\prime}$ compatible with the agent's thought, $\mathrm{s}\left(t_{2^{*}}\right)\left(\mathrm{c}^{\prime}\right)$ should not be entirely after $\mathrm{c}_{\mathrm{T}}^{\prime}$ (by (iii')). Hence if the agent is not mistaken about the time, his thought will have to be about an interval that includes both the time of the speaker's utterance and the time of the agent's thought act, as is desired.

\subsubsection{Extension to Mood}

The logic of this argument can be extended to mood by stating for the indicative a stipulation that is roughly the world analogue of the Upper Limit Constraint. The idea is that a world term in the immediate scope of a context variable $c_{i}$ must denote, among others, the world of the denotation of $c_{i}$. Thus the constraint in (38) is extended by adding the following clause:

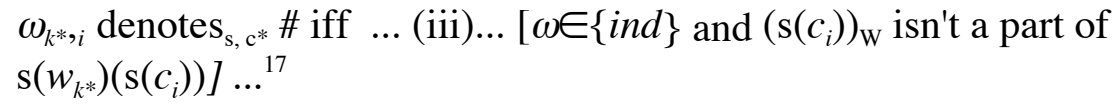

Let us see an application right away. In order to avoid the issue of presupposition projection in subjunctive conditionals, I consider an example in which an indicative verb is embedded under a subjunctive attitude verb which is itself embedded under 'il faut que' ('it is necessary that'), which triggers the subjunctive. As before I only include the most important part of the failure conditions (a full derivation is given in Appendix B):

(41) a. (Il faut qu') il pense qu'elle est enceinte

(It is necessary that) he think-subj that she is-ind pregnant

\footnotetext{
${ }^{17}$ The rule stated in Appendix B looks more abstract because it encompasses both (38) and (40).
} 
b. he think-pres $_{1}-$ subj $_{1}$ that $_{\mathrm{c}_{1} \mathrm{~F}}$ she $_{2}$ be-pregnant-c ${ }_{1}^{\mathrm{F}}$-ind ${ }_{2}$, with $\mathrm{F}=<$ he, pres, subj>

c. he think-pres $_{1}-$ subj $_{1}$ that $_{\mathrm{c}_{1} \mathrm{~F}}$ she $_{2^{*}, 1}$ be-pregnant-c ${ }_{1}^{\mathrm{F}} \mathrm{T}^{-}$ind $_{2^{*}, 1}$, with $\mathrm{F}=<$ he, pres, subj $>$

d. (c) is weird ${ }_{\mathrm{s}, \mathrm{c}^{*}}$ iff ... for some $\mathrm{c}^{\prime}$ in think $\mathrm{fs}^{<\mathrm{s}\left(x_{l}\right), \mathrm{s}(t l), \mathrm{s}\left(w_{l}\right)>} \ldots$

(i') $\mathrm{s}\left(w_{2}\right)$ is not $\mathrm{c}^{*}{ }_{\mathrm{w}}$, or

(ii') there is a context c corresponding to

$<\mathrm{s}\left(x_{1}\right), \mathrm{s}\left(t_{1}\right), \mathrm{s}\left(w_{1}\right)>$ and [ $\mathrm{s}\left(w_{2^{*}}\right)$ isn't vivid for $\mathrm{c}$ or $\mathrm{s}\left(w_{2}\right)$ is not a part of $\left.\mathrm{s}\left(w_{2^{*}}\right)(\mathrm{c})\right]$, or

(iii') $\mathrm{s}\left(w_{2^{*}}\right)\left(\mathrm{c}^{\prime}\right)$ does not contain $\mathrm{c}^{\prime}{ }_{\mathrm{w}} \cdots$

e. Pronunciation: he think-pres-subj that she be-pregnant-pres-ind

After the De Re Transformation, the world variable $i n d_{2}$ is replaced with $i n d_{2^{*}}$, l, which denotes a world description whose argument is the variable $c_{1}$, as indicated by the second subscript of $i n d_{2^{*}, l}$. In order to avoid a presupposition failure, $w_{2^{*}}$ must denote in the context of the agent's speech act $\mathrm{c}$ a group of worlds that includes $\mathrm{s}\left(w_{2}\right)$ (by (ii')), hence $\mathrm{c}^{*}{ }_{\mathrm{w}}$, the world of the actual context (since by (i') a presupposition failure ensues if $\mathrm{s}\left(w_{2}\right) \neq \mathrm{c}^{*}{ }_{\mathrm{w}}$ ). Moreover, by (iii'), for each context $\mathrm{c}^{\prime}$ compatible with the agent's thought, $\mathrm{s}\left(w_{2^{*}}\right)\left(\mathrm{c}^{\prime}\right)$ must also include $\mathrm{c}^{\prime}{ }_{\mathrm{w}}$. The latter is the contribution made by the Generalized Upper Limit Constraint.

Let us make things more concrete. Suppose the agent of the attitude is John, who is thinking about Mary; and assume that the salient description $\square$ is: the worlds in which Mary has the same symptoms as she in fact does, or (equivalently) the worlds in which Mary has these symptoms, pointing to Mary's current condition [the semantic value of this description is: $\square c$ the worlds $w$ such that Mary has the same symptoms in $w$ as in $c_{W}$. Does $\square$ satisfy the presuppositions of (41)? Let us assume that (i') is satisfied. (iii'), which is the contribution of the Generalized Upper Limit Constraint, requires that for every context $\mathrm{c}^{\prime}$ compatible with what John thinks in the actual world $\mathrm{c}^{*}{ }_{\mathrm{w}}$ at the time of utterance $\mathrm{c}^{*}{ }_{\mathrm{T}}, \square$ uttered in $\mathrm{c}^{\prime}$ should denote a group of worlds that includes $\mathrm{c}_{\mathrm{W}}^{\prime}$; this is trivially the case since Mary certainly has the same symptoms in $\mathrm{c}^{\prime}{ }_{\mathrm{W}}$ as she does in... $\mathrm{c}^{\prime}{ }_{\mathrm{w}}$. Thus due to the indexical nature of the description ('the same symptoms as she does in the actual world'), the Generalized Upper Limit Constraint is automatically satisfied. Condition (ii') requires that the description $\square$, uttered in the counterfactual world $\mathrm{s}\left(w_{l}\right)$, should denote a group that includes the actual world $\mathrm{c}^{*}{ }_{\mathrm{w}}$. In other words, it should be presupposed that Mary has the same symptoms in $\mathrm{s}\left(w_{l}\right)$ as in the actual world. To put it more generally, Condition (ii') forces the counterfactual worlds that are 'talked about' in (41)a to share some salient property $\mathrm{P}$ with the actual world, where $\mathrm{P}$ represents a natural way in which the agent of the attitude (in the counterfactual world) would characterize the world he thinks he lives in. Speakers' intuitions are certainly not sharp enough to validate this prediction, especially since everything depends on the choice of the 
description $\square$, for which there is no independent evidence. However it does seem to be presupposed in (41)a that the counterfactual situations that are talked about (=the situations compatible with what the speaker deems desirable) somehow share some salient property with the actual world. No such impression would hold if the embedded indicative were replaced with a subjunctive: Il faut qu'il pense qu'elle soit enceinte. The present theory can analyze this contrast as a consequence of Condition (ii').

Let us now see what would go wrong if we didn't have Condition (ii') or Condition (iii') (for simplicity I am assuming that there is a context that corresponds to $\left.<\mathrm{s}\left(x_{1}\right), \mathrm{s}\left(t_{1}\right), \mathrm{s}\left(w_{1}\right)>\right)$. Without the requirement that $\mathrm{s}\left(w_{2}\right)$ (i.e. $\left.\mathrm{c}^{*}{ }_{\mathrm{w}}\right)$ be a part of $\mathrm{s}\left(w_{2^{*}}\right)(\mathrm{c})$, there would be no sense in which the agent's thought has be about the actual world. Without the vividness condition, any kind of description would be allowed, for instance: the worlds in which Mary is pregnant. Now there is no doubt that John would assent to: 'Mary is pregnant in the worlds in which Mary is pregnant'. But this shouldn't be enough to attribute to John a thought about the actual world, even if the actual world is one in which Mary is in fact pregnant. Something more must be required of the description. In the above example (the worlds in which Mary has these symptoms [pointing]), we can assume that the vividness requirement is satisfied by the fact that a term of direct reference is used in the definition of the description. But this is not even the beginning of a theory of what 'vivid' means when applied to a description of worlds. All the present argument shows is that some constraint of this form is needed if the theory is to get off the ground. This is of course unsurprising since we saw that, in the case of De Re readings of individual terms, such a constraint is also needed (see Kaplan 1969 for an attempt to spell out a theory of vividness for descriptions of individuals).

Without Condition (iii'), we would allow the salient description to be one that, according to John, does not pick out the world that he thinks he lives in. For instance the description could be: the closest world in which Mary has a big belly [whose semantic value is: $\square c$ the closest worlds from $c_{W}$ in which Mary has a big belly]. If so the thought attributed to John could very well be a conditional, for instance: If Mary had a big belly, she would be pregnant ${ }^{18}$. But here intuitions are, I believe, very sharp: (41)a entails that in the worlds compatible with what the speaker deems desirable, John would assent to something of the form 'Mary is pregnant', not to a merely conditional thought such as 'If she had a big belly, etc.'. The desired entailment would disappear if Condition (iii') were done away with. I conclude that the Generalized Upper Limit Constraint is both necessary and (almost) sufficient to account for the modal analogues of Double Access Readings, at least when it is embedded in a theory of De Re attitudes about possible worlds.

\footnotetext{
${ }^{18}$ Of course Condition (ii') would still require that in the counterfactual context in which John is thinking the description the closest world in which Mary has a big belly should in fact pick out the actual world $\mathrm{c}^{*}{ }_{\mathrm{w}}$
} 


\section{Appendix. Fragments}

\section{A. A Fragment with Quantification Over Contexts and Rules of Agreement for Person, Tense and Mood}

Definitions

- Vocabulary and Syntax

口 Terms and Predicates

Terms

(i) Bare variables: $x_{k}$ (individuals), $t_{k}$ (times), $w_{k}$ (worlds), $c_{k}^{F}$ (contexts) for each $\mathrm{k} \square \mathrm{IN}$ and each element $\mathrm{F}$ of $\{\mathrm{e}$, he, she $\} \square\{\mathrm{e}$, pres, past $\} \square\{\mathrm{e}$, ind,$s u b j\}$ (ii) Simple pronominal variables: $h e_{k}$, she $_{k}$, (pronouns), pres $_{k}$, past $_{k}$ (tenses), ind $_{k}, s_{u b j}$ (moods), for each $\mathrm{k} \square \mathrm{IN}$

(iii) Coordinates of contexts: $c_{A}$ (individuals), $c_{T}$ (times), $c_{W}$ (worlds), for each context variable c.

(iv) Complex pronominal variables: If $\mathrm{t}$ is a time term formed by (i)-(iii), $\mathrm{fut}_{k}(t)$ is a complex tense.

\section{Predicates}

-Simple predicates with 1 individual argument, 1 time argument and 1 world argument: be-elected, be leaving, be pregnant

-Attitude verbs: hope, think, decide, say...

\section{$\square \quad$ Formulas}

If $\mathrm{i}$ is an individual term, $\mathrm{t}$ is a time term and $\mathrm{w}$ is a world term, and if $\mathrm{P}$ is a simple predicate, then $i P-t-w$ is a formula.

Note: In a more common logical syntax, $i P-t-w$ would be written as: $P(i, t$, w)

If $\square$ and $\square$ are formulas, then $(\square \& \square),(\square v \square)$ and $\square \square$ are formulas

If $\square$ is a formula, $\mathrm{P}$ is an attitude verb, $\mathrm{i}$ is an individual term, $\mathrm{t}$ is a time term, $\mathrm{W}$ is a world term, and $\mathrm{k}$ is an integer, then $i P-t-w t t_{c_{k^{F}}} \square$ is a formula, where $\mathrm{F}$ is the triple of $\{\mathrm{e}, h e, s h e\} \square\{\mathrm{e}$, pres, past $\} \square\{\mathrm{e}$, ind, subj\} whose first coordinate is he/she if he/she appears in i, and e otherwise; whose second coordinate is pres/past if pres/past appears in t, and e otherwise; and whose third coordinate is ind/subj if ind/subj appears in $\mathrm{w}$, and e otherwise.

Notes: 
A. By appear in $i$ (resp. appear in t, appear in $w$ ) is meant: appear anywhere in $i$ (resp. t, w), including as a coordinate of a triple of features $F$ if $i$ is of the form $\mathrm{c}_{\mathrm{k}}^{\mathrm{F}}$ (resp. $\mathrm{c}_{\mathrm{k}}^{\mathrm{F}}, \mathrm{c}_{\mathrm{k}}{ }_{\mathrm{W}}$ ). This will be crucial in example (iv).

B. We will say that $\square$ is in the scope of $i P-t-w$ that $_{c_{k} F}$

C. F does not play any semantic role but serves to keep track of the features that must pronounced in the phonological component as a result of the rules of person, tense and mood agreement. Note that the future morpheme fut never appears in $\mathrm{F}$ (because the future morpheme does not trigger any agreement phenomena).

\section{- Denotation and Truth}

An assignment function $\mathrm{s}$ is a function that assigns to each variable $x_{k}$ an individual, to each variable $t_{k}$ a moment, to each variable $w_{k}$ a world and to each variable $c_{k}$ a context. If $\square$ is a variable and $\mathrm{d}$ is an object that can be a value of $\square, \mathrm{s}[\square \square \mathrm{d}]$ is the assignment defined by: (i) for each variable $\square$ different from $\square \mathrm{s}[\square \mathrm{d}](\square=\mathrm{s}(\square)$, and (ii) $\mathrm{s}[\square \mathrm{d}](\square) \mathrm{d}$

Assumptions:

(i) Each context $\mathrm{c}$ has exactly one agent $\mathrm{c}_{\mathrm{A}}$, one time of occurrence $\mathrm{c}_{\mathrm{T}}$ and one world of occurrence $\mathrm{c}_{\mathrm{W}}$.

(ii) For each attitude verb $\mathrm{P}$ and each triple of the form $<\underline{\mathrm{i}}, \underline{\mathrm{t}}, \underline{\mathrm{w}}\rangle$, either (a) there is no attitude of $P$-ing at $\underline{\mathrm{t}}$ in $\underline{\mathrm{w}}$ by $\underline{\mathrm{i}}$, or else (b) there is a (possibly

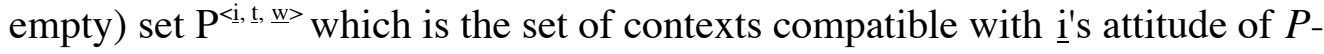
ing at $\underline{t}$ in $\underline{w}$.

Let $\mathrm{c}^{*}$ be the context of utterance, let $\mathrm{k}$ be any integer and let $\mathrm{s}$ be an assignment function. Then:

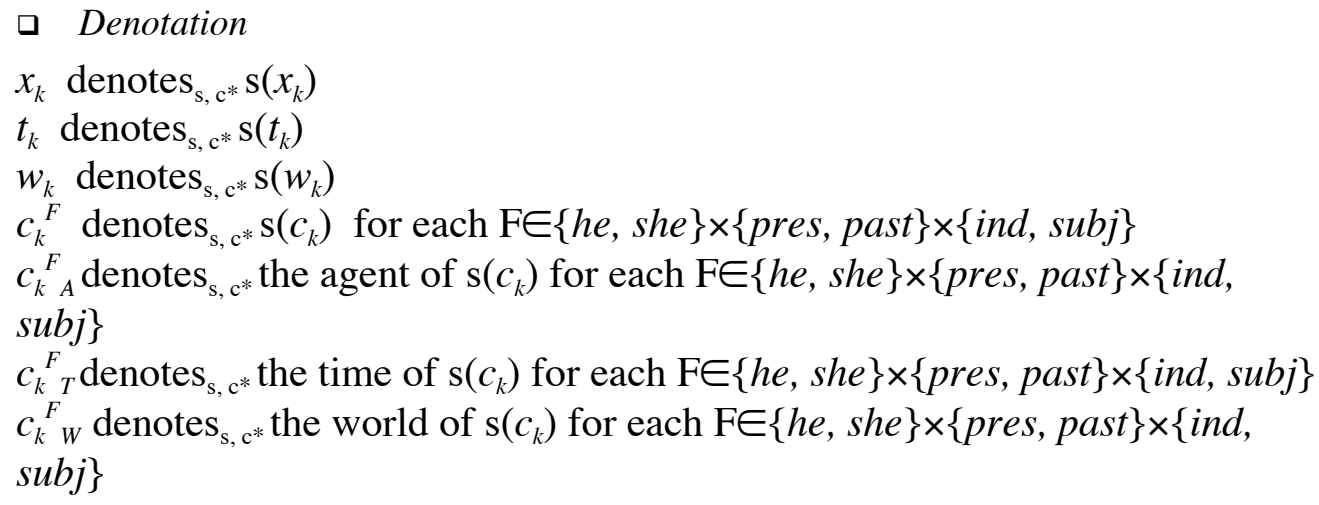


pres $_{k}$ denotes $_{\mathrm{s}, \mathrm{c}^{*}} \#$ iff $\mathrm{s}\left(t_{k}\right)$ isn't the time of $\mathrm{c}^{*}$. Otherwise it denotes ${\mathrm{s}, \mathrm{c}^{*}} \mathrm{~s}\left(t_{k}\right)$ past $_{k}$ denotes $_{\mathrm{s}, \mathrm{c}^{*}} \#$ iff $\mathrm{s}\left(t_{k}\right)$ isn't before the time of $\mathrm{c}^{*}$. Otherwise it denotes $\mathrm{s}_{\mathrm{s} \mathrm{c}^{*}}$ $\mathrm{s}\left(t_{k}\right)$

ind $_{k}$ denotes $_{\mathrm{s}, \mathrm{c}^{*}} \#$ iff $\mathrm{s}\left(w_{k}\right)$ isn't $\mathrm{c}^{*}{ }_{\mathrm{w}^{*}}$. Otherwise it denotes ${\mathrm{s}, \mathrm{c}^{*}} \mathrm{~s}\left(w_{k}\right)$.

subj $_{k}$ denotes $_{\mathrm{s}, \mathrm{c}^{*}} \mathrm{~s}\left(w_{k}\right)$

Note: This is an extremely crude analysis of mood, but it will suffice for our purposes. In a more elaborate treatment, one could use Stalnaker's (1975) notion of Common Ground to give a definition in which $i n d_{k}$ denotes $_{\mathrm{s}, \mathrm{c}^{*}} \#$ iff $\mathrm{s}\left(w_{k}\right)$ isn't in $\left\{\mathrm{c}_{\mathrm{w}}: \mathrm{c}\right.$ is compatible with what $\mathrm{c}^{*}{ }_{\mathrm{A}}$ believes at $\mathrm{c}^{*}{ }_{\mathrm{T}}$ in $\left.\mathrm{c}^{*}{ }_{\mathrm{w}}\right\}$. The analysis of the subjunctive would also have to be refined (in the present account, the subjunctive introduces no presupposition at all).

$f u t_{k}\left(\square\right.$ denotes $_{\mathrm{s}, \mathrm{c}^{*}} \#$ iff $\square$ denotes $_{\mathrm{s}, \mathrm{c}^{*}} \#$ or $\square$ denotes $_{\mathrm{s}, \mathrm{c}^{*}}$ some moment $\mathrm{t}$ and $\mathrm{s}\left(t_{k}\right)$ isn't after t. Otherwise $f u t_{k}\left(\square\right.$ denotes $_{\mathrm{s}, \mathrm{c}^{*}} \mathrm{~s}\left(t_{k}\right)$

\section{口 Truth}

-If $\square$ is an atomic formula $i P-t-w$, where $\mathrm{P}$ is a simple predicate, $\square$ is weird $\mathrm{s}_{\mathrm{s}, \mathrm{c}^{*}}$ iff at least one of its arguments denotes $s_{\mathrm{s}, \mathrm{c}^{*}} \#$. Otherwise it is true $\mathrm{s}_{\mathrm{c} \mathrm{c}^{*}}$ iff $<\underline{\mathrm{i}}, \underline{\mathrm{t}}$, $\underline{\mathrm{w}}>$ satisfies $P$, where $\underline{\mathrm{i}}, \underline{\mathrm{t}}, \underline{\mathrm{w}}$ are the denotations $\mathrm{s}_{\mathrm{s}, \mathrm{c}^{*}}$ of $\mathrm{i}, \mathrm{t}, \mathrm{w}$ respectively.

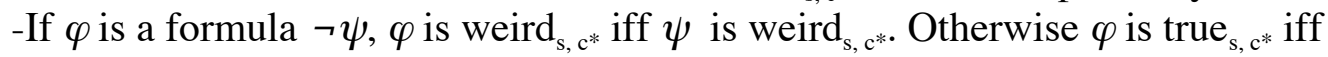
$\square$ is not true $\mathrm{s}, \mathrm{c}$ *

-If $\square$ is a formula $(\square \& \square)(\operatorname{resp} .(\square v \square)), \square$ is weird ${\text { s, } \mathrm{c}^{*}}$ iff $\square$ is weird $_{\mathrm{s}, \mathrm{c}^{*}}$ or $\square$ is weird ${ }_{\mathrm{s}, \mathrm{c}^{*}}$. Otherwise $\square$ is true $_{\mathrm{s}, \mathrm{c}^{*}}$ iff $\square$ is true $_{\mathrm{s}, \mathrm{c}^{*}}$ and $\square$ is true $\mathrm{s}_{\mathrm{s}, \mathrm{c}^{*}}($ resp. $\square$ is true $_{\mathrm{s}, \mathrm{c}^{*}}$ or $\square$ is true $\mathrm{s}_{\mathrm{s} \mathrm{c}^{*}}$ ).

-If $\square$ is a formula $i P-t-w$ that $_{c_{k} F} \square$, where $\mathrm{P}$ is an attitude verb, $\square$ is weird s, $^{*}$ iff (i) $i, t$ or $w$ (or several of them) denotes $\mathrm{s}_{\mathrm{s}, \mathrm{c}^{*}} \#$ or (ii) $i, t$ or $w$ denote $_{\mathrm{s}, \mathrm{c}^{*}}$ respectively an individual $\underline{i}$, a time $\underline{t}$ and a world $\underline{\mathrm{w}}$ and there is an attitude of

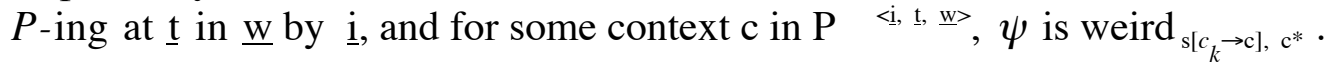
Otherwise, $\square$ is true ${ }_{\mathrm{s}, \mathrm{c}^{*}}$ iff there is an attitude of $P$-ing by $\underline{\mathrm{i}}$ at $\underline{\mathrm{t}}$ in $\underline{\mathrm{w}}^{19}$, and for every context $\mathrm{c}$ in $\mathrm{P}^{<\mathrm{i}, \mathrm{t}, \underline{\mathrm{w}}>}, \square$ is true $\mathrm{s}_{\mathrm{s}\left[c_{k} \square \mathrm{c}\right], \mathrm{c}^{*}}$

\section{- Agreement and Pronunciation}

A formula is pronounced by: (i) erasing all numbers, (ii) replacing each occurrence of $c^{F}{ }_{A}$ with the first coordinate of $\mathrm{F}, c^{F}{ }_{T}$ with the second coordinate of $\mathrm{F}$, and $c^{F}{ }_{W}$ with the third coordinate of $\mathrm{F}$, for each $\mathrm{F} \square\{h e$, she\} $\square\{$ pres, past $\} \square\{$ ind, subj\} and (iii) eliminating all remaining context variables.

\footnotetext{
${ }^{19}$ On the present definition, if there is no attitude of vacuously false. 
Examples

(i) a. He hopes that he is elected / He hopes that he himself is elected / He hopes to be elected (De Se Reading for the embedded pronoun)

b. he hope-pres $_{1}$-ind that $_{\mathrm{c}_{1} \mathrm{~F}} \mathrm{c}_{1}{ }_{\mathrm{A}}^{\mathrm{F}}$ be-elected- ${ }_{1}{ }_{\mathrm{T}^{-}} \mathrm{c}_{1}{ }_{1}^{\mathrm{F}}$, with $\mathrm{F}=<$ he, pres, ind $>$

c. (b) is weird ${ }_{\mathrm{s}, \mathrm{c}^{*}}$ iff $\mathrm{s}\left(x_{1}\right)$ is not male at $\mathrm{c}^{*}{ }_{\mathrm{T}}$ in $\mathrm{c}^{*}{ }_{\mathrm{w}}$ or $\mathrm{s}\left(t_{1}\right)$ is not $\mathrm{c}^{*}{ }_{\mathrm{T}}$ or $\mathrm{s}\left(w_{l}\right)$ is not $\mathrm{c}^{*}{ }_{\mathrm{w}}$. Otherwise (b) is true ${\mathrm{s}, \mathrm{c}^{*}}$ iff there is an attitude of hoping by $\mathrm{s}\left(x_{l}\right)$ at $\mathrm{c}^{*}{ }_{\mathrm{T}}$ in $\mathrm{c} *{ }_{\mathrm{w}}$ and for every context $\mathrm{c}$ in hope $\mathrm{es}^{\mathrm{s}(\mathrm{x} 1 \mathrm{l}), \mathrm{s}(\mathrm{t} 1), \mathrm{s}(\mathrm{w} 1)\rangle},<\mathrm{c}_{\mathrm{A}}$, $\mathrm{c}_{\mathrm{T}}, \mathrm{c}_{\mathrm{W}}>$ satisfies be-elected.

d. (b) is pronounced as: he hope-pres-ind that he be-elected-pres-ind

Note: Even if some contexts compatible with $\mathrm{s}\left(x_{1}\right)$ 's hope at $\mathrm{c}^{*}{ }_{\mathrm{T}}$ in $\mathrm{c}^{*}{ }_{\mathrm{w}}$ are contexts whose agent is a woman, the sentence is predicted to be grammatical since the features of the embedded pronoun he are present in the pronunciation only.

(ii) a. He hopes that he is elected (De Re Reading for the embedded he)

b. he $e_{1}$ hope-pres -ind $_{1}$ that $_{\mathrm{c}_{1} \mathrm{~F}}$ he $\mathrm{e}_{1}$ be-elected-c ${ }_{1}^{\mathrm{F}} \mathrm{T}^{-} \mathrm{c}_{1}^{\mathrm{F}} \mathrm{W}$, with $\mathrm{F}=<$ he, pres, ind $>$

c. (b) is weird $\mathrm{s}_{\mathrm{s}, \mathrm{c}^{*}}$ iff $\mathrm{s}\left(x_{1}\right)$ is not male at $\mathrm{c}^{*}{ }_{\mathrm{T}}$ in $\mathrm{c}^{*}{ }_{\mathrm{w}}$ or $\mathrm{s}\left(t_{1}\right)$ is not $\mathrm{c}^{*}{ }_{\mathrm{T}}$ or $\mathrm{s}\left(w_{l}\right)$ is not $\mathrm{c}^{*}{ }_{\mathrm{w}}$. Otherwise (b) is true ${\mathrm{s}, \mathrm{c}^{*}}$ iff there is an attitude of hoping by $\mathrm{s}\left(x_{1}\right)$ at $\mathrm{c}^{*}{ }_{\mathrm{T}}$ in $\mathrm{c}^{*}{ }_{\mathrm{w}}$ and for every context $\mathrm{c}$ in hope $\mathrm{e}^{<\left(x_{I}\right), \mathrm{s}(t), \mathrm{s}\left(w_{I}\right)>},<\mathrm{s}\left(x_{l}\right)$, $\mathrm{c}_{\mathrm{T}}, \mathrm{c}_{\mathrm{W}}>$ satisfies be-elected.

d. (b) is pronounced as: he hope-pres-ind that he be-elected-pres-ind

(iii) a. She thought that he (e.g. Clinton) was president (De Se Reading for the embedded tense)

b. she think-past $_{1}-$ ind $_{1}$ that $_{\mathrm{c}_{1} \mathrm{~F}}$ he $_{2}$ be-president-c ${ }_{1} \mathrm{~T}_{\mathrm{T}}-\mathrm{c}_{1}{ }_{\mathrm{W}}^{\mathrm{F}}$, with $\mathrm{F}=<$ she, past, ind $>$

c. (b) is weird ${ }_{\mathrm{s}, \mathrm{c}^{*}}$ iff $\mathrm{s}\left(x_{1}\right)$ is not female at $\mathrm{c}^{*}{ }_{\mathrm{T}}$ in $\mathrm{c}^{*}{ }_{\mathrm{w}}$ or $\mathrm{s}\left(x_{2}\right)$ is not male at $\mathrm{c}^{*}{ }_{\mathrm{T}}$ in $\mathrm{c}^{*}{ }_{\mathrm{w}}$ or $\mathrm{s}\left(t_{1}\right)$ does not precede $\mathrm{c}^{*}{ }_{\mathrm{T}}$ or $\mathrm{s}\left(w_{1}\right)$ is not $\mathrm{c}^{*}{ }_{\mathrm{w}}$. Otherwise (b) is true ${ }_{\mathrm{s}, \mathrm{c}^{*}}$ iff there is an attitude of thinking by $\mathrm{s}\left(x_{1}\right)$ at $\mathrm{c}^{*}{ }_{\mathrm{T}}$ in $\mathrm{c}^{*}{ }_{\mathrm{W}}$ and for every context $\mathrm{c}$ in think ${ }^{\left.<\mathrm{s}\left(x_{I}\right), \mathrm{s}\left(t_{I}\right), \mathrm{s}\left(w_{I}\right)\right\rangle},<\mathrm{s}\left(x_{2}\right), \mathrm{c}_{\mathrm{T}}, \mathrm{c}_{\mathrm{W}}>$ satisfies $b e-$ president.

d. (b) is pronounced as: she think-past-ind that he be-president-past-ind

Note: Even if for some context c compatible with $\mathrm{s}\left(x_{1}\right)$ 's hope at time $\mathrm{s}\left(t_{1}\right)$ in $\mathrm{c}^{*}{ }_{\mathrm{W}}, \mathrm{c}_{\mathrm{T}}$ is not before $\mathrm{c}_{\mathrm{T}}^{*}$, the sentence is predicted to be grammatical since the features of the embedded past tense are present in the pronunciation only.

(iv) a. He decided (yesterday) that (tomorrow) he would say (to his mother) that he was leaving (the embedded past tenses need not be interpreted) 


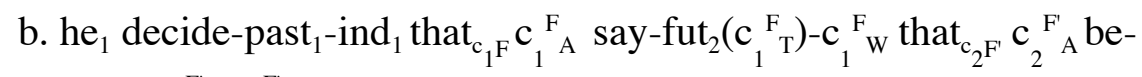
leaving- $\mathrm{C}_{2}^{\mathrm{F}^{\prime}} \mathrm{T}^{-} \mathrm{C}_{2}{ }^{\mathrm{F}^{\prime}} \mathrm{W}$ with $\mathrm{F}=\mathrm{F}^{\prime}=<$ he, past, ind $>$ c. (b) is weird ${ }_{\mathrm{s}, \mathrm{c}^{*}}$ iff $\mathrm{s}\left(x_{l}\right)$ is not male at $\mathrm{c}^{*}{ }_{\mathrm{T}}$ in $\mathrm{c}^{*}{ }_{\mathrm{w}}$ or $\mathrm{s}\left(t_{l}\right)$ does not precede $\mathrm{c}^{*}{ }_{\mathrm{T}}$ or $\mathrm{s}\left(w_{l}\right)$ is not $\mathrm{c}^{*}{ }_{\mathrm{W}}$ or (if none of the three preceding conditions holds) there is an attitude of deciding by $\mathrm{s}\left(x_{1}\right)$ at $\mathrm{s}\left(t_{l}\right)$ in $\mathrm{c}^{*}{ }_{\mathrm{w}}$ and for some context $\mathrm{c}$ in decide $\mathrm{s}^{\left.<\left(x_{I}\right), \mathrm{s}\left(t_{I}\right), \mathrm{s}\left(w_{I}\right)\right\rangle} \mathrm{s}\left(t_{2}\right)$ does not follow $\mathrm{c}_{\mathrm{T}}$. Otherwise (b) is true ${\mathrm{s}, \mathrm{c}^{*}}$ iff there is an attitude of deciding by $\mathrm{s}\left(x_{1}\right)$ at $\mathrm{s}\left(t_{1}\right)$ in $\mathrm{c}^{*}{ }_{\mathrm{w}}$ and for every context $\mathrm{c}$ in decide ${ }^{\left\langle\mathrm{s}\left(x_{I}\right), \mathrm{s}\left(t_{1}\right), \mathrm{s}\left(w_{I}\right)\right\rangle}$, there is an attitude of saying by $\mathrm{c}_{\mathrm{A}}$ at $\mathrm{s}\left(t_{2}\right)$ in $\mathrm{c}_{\mathrm{W}}$ and for every context $\mathrm{c}^{\prime}$ in $\mathrm{say}^{<\mathrm{c}_{\mathrm{A}}, \mathrm{s}\left(t_{2}\right), \mathrm{c}_{\mathrm{W}}>}$ $<\mathrm{c}_{\mathrm{A}}^{\prime}, \mathrm{c}_{\mathrm{T}}^{\prime}, \mathrm{c}_{\mathrm{W}}^{\prime}>$ satisfies be-leaving.

d. (b) is pronounced as: he decide-past-ind that he say-fut(past)-ind that he be-leaving-past-ind

(v) a. She thinks that he is president (the embedded mood need not be interpreted)

b. she think-pres $_{1}-$ ind $_{1}$ that $_{\mathrm{c}_{1} \mathrm{~F}}$ he $_{2}$ be-president-c ${ }_{1}{ }_{\mathrm{T}}-\mathrm{c}_{1}^{\mathrm{F}} \mathrm{W}$, with $\mathrm{F}=<$ she, past, ind $>$

c. (b) is weird ${\mathrm{s}, \mathrm{c}^{*}}$ iff $\mathrm{s}\left(x_{1}\right)$ is not female at $\mathrm{c}^{*}{ }_{\mathrm{T}}$ in $\mathrm{c}^{*}{ }_{\mathrm{w}}$ or $\mathrm{s}\left(x_{2}\right)$ is not male at $\mathrm{c}^{*}{ }_{\mathrm{T}}$ in $\mathrm{c}^{*}{ }_{\mathrm{w}}$ or $\mathrm{s}\left(t_{l}\right)$ is not the time of $\mathrm{c}^{*}$ or $\mathrm{s}\left(w_{l}\right)$ is not in $\mathrm{c}^{*}{ }_{\mathrm{w}}$.

Otherwise (b) is true ${\mathrm{s}, \mathrm{c}^{*}}$ iff there is an attitude of thinking by $\mathrm{s}\left(x_{1}\right)$ at $\mathrm{s}\left(t_{1}\right)$ in $\mathrm{c}^{*}{ }_{\mathrm{w}}$ and for every context $\mathrm{c}$ in think $\mathrm{k}^{\left.<\mathrm{s}\left(x_{I}\right), \mathrm{s}(t I), \mathrm{s}\left(w_{I}\right)\right\rangle},\left\langle\mathrm{s}\left(x_{2}\right), \mathrm{c}_{\mathrm{T}}, \mathrm{c}_{\mathrm{W}}\right\rangle$ satisfies be-president.

d. (b) is pronounced as: she think-pres-ind thathe be-president-pres-ind

Note: Even if (as is extremely likely) for some context $\mathrm{c}$ in think ${ }^{\left.<\mathrm{s}\left(x_{l}\right), \mathrm{s}(t)\right), \mathrm{s}(w I)>}$ $\mathrm{c}_{\mathrm{W}} \neq \mathrm{c} *{ }_{\mathrm{w}}$, the sentence is still predicted to be grammatical since the features of the embedded mood are present in the pronunciation only.

\section{B. Adding Kaplan's Analysis of Quantifying In and a Generalized Upper Limit Constraint}

Definitions

- Vocabulary and Syntax

口 Terms and Predicates

Same as A., but replace (ii) with (ii') and (iv) with (iv'):

(ii') Simple pronominal variables: same as (ii), adding $h e_{k^{*},}{ }_{i} s h e_{k^{*},}{ }_{i}$ (pronouns), pres $_{k^{*},}$, past $_{k^{*},}$, (tenses), ind $_{k^{*},}{ }_{i} \operatorname{subj}_{k^{*},}$ (moods), for each k, i $\square \mathrm{IN}$

(iv') Complex pronominal variables: If $\mathrm{t}$ is a time term formed by (i)-(ii')-(iii), $f u t_{k}(t)$ and $f u t_{k^{*}, i}(t)$ are complex tenses. 


\section{口 Formulas}

The well-formed formulas are those of A, modified by the following transformation:

De Re Transformation: If $k$ is the index of a free variable in the immediate scope of an attitude verb introducing a variable $c_{i}^{F}$, replace $\mathrm{k}$ with $\mathrm{k}^{*}, \mathrm{i}$.

Note: By free variable is meant: any free variable (i.e. a bare variable, a simple pronominal variable, or a complex pronominal variable). By variable $v$ is in the immediate scope of the attitude verb $A$ is meant: $v$ is in the scope of $A$ and there is no other attitude verb $A^{\prime}$ which is in the scope of $A$ and such that $v$ is in the scope of $A^{\prime}$.

\section{- Denotation and Truth}

An assignment function $\mathrm{s}$ is a function that assigns to each variable $x_{k}$ a singular individual, to each variable $t_{k}$ a singular moment, to each variable $w_{k}$ a singular world, to each variable $c_{k}$ a context, to each variable $x_{k^{*}}$ a function from contexts to (singular or plural) individuals, to each variable $t_{k^{*}}$ a function from contexts to time intervals, and to each variable $w_{k^{*}}$ a function from contexts to groups (=pluralities) of worlds.

Terminology: For individuals, times and worlds we adopt a mereology with a part-of relation. For times only intervals and singular moments are considered (in other words, the only plural moments are intervals). Correspondingly, predicates are taken to be satisfied by singular or plural objects.

\section{․ Denotation}

Let $i P-t-w$ that $_{c_{i} F}$ be the attitude verb in the immediate scope of which the following terms appear. Let $\underline{\mathrm{i}}, \underline{\mathrm{t}}, \underline{\mathrm{w}}$ be the denotations $\mathrm{s}_{\mathrm{s}, \mathrm{c}^{*}}$ of $i, t, w$ respectively. Then for each $\square \square\{h e$, she, pres, past, ind $\}$, for each time term $\mathrm{t}$, and for each $\mathrm{k}, \mathrm{i} \square \mathrm{IN}$, the following holds, where $\square$ is ' $\mathrm{x}$ ' if $\square \square\{h e$, she $\}$, ' $\mathrm{t}$ ' if $\square \square\{$ pres, past $\}$ and ' $\mathrm{w}$ ' if $\square \square\{$ ind $\}$ :

$$
\begin{aligned}
& \square_{k^{*}, i} \text { denotes }_{\mathrm{s}, \mathrm{c}^{*}} \# \text { iff (i) } \square_{k} \text { denotes }_{\mathrm{s}, \mathrm{c}^{*}} \# \text {, or } \\
& \text { (ii) there is a context } \mathrm{c} \text { corresponding to }<\underline{\mathrm{i}}, \underline{\mathrm{t}}, \underline{\mathrm{w}}>\text { and } \\
& {\left[\mathrm{s}\left(\square_{k}\right) \text { isn't a part of } \mathrm{s}\left(\square_{k^{*}}\right)(\mathrm{c}) \text { or } \mathrm{s}\left(\square_{k^{*}}\right) \text { isn't vivid for } \mathrm{c}\right] \text {, }} \\
& \text { or } \\
& \text { (iii) }\left[\square \square\{\text { pres, past }\} \text { and } \mathrm{s}\left(\square_{k^{*}}\right)\left(\mathrm{s}\left(c_{i}\right)\right)\right. \text { is entirely after } \\
& \left.\left(\mathrm{s}\left(c_{i}\right)\right)_{\mathrm{T}}\right] \text { or } \mathrm{L} \square\{\text { ind }\} \text { and }\left(\mathrm{s}\left(c_{i}\right)\right)_{\mathrm{W}} \text { isn't a part of } \\
& \left.\mathrm{s}\left(\square_{k^{*}}\right)\left(\mathrm{s}\left(c_{i}\right)\right)\right] \text {. }
\end{aligned}
$$

Otherwise $\square_{k^{*},{ }_{i}}$ denotes ${\mathrm{s}, \mathrm{c}^{*}} \mathrm{~s}\left(\square_{k^{*}}\right)\left(\mathrm{s}\left(c_{i}\right)\right)$ 
Note: (i) is the only constraint that would hold if the De Re Transformation had not been applied. (ii) is the requirement that $s\left(\square_{k^{*}}\right)$ be a vivid name of $\mathrm{s}\left(\square_{k}\right)$ for the agent of the attitude, at the time of the attitude and at the world of the attitude. (iii) is a generalized version of the Upper Limit Constraint, applied both to tense and to mood. (Note that the subjunctive, as the future, does not have to obey this constraint).

fut $_{k^{*}, i_{i}}(t)$ denotes $_{\mathrm{s}, \mathrm{c}^{*}} \#$ iff (i) $t$ denotes $_{\mathrm{s}, \mathrm{c}^{*}} \#$ or

(ii) $t$ denotes $_{\mathrm{s}, \mathrm{c}^{*}}$ a moment $\underline{\mathrm{t}}$ and $\mathrm{s}\left(t_{k^{*}}\right)\left(\mathrm{s}\left(c_{i}\right)\right)$ is not

entirely after $\underline{t}$, or

(iii) there is a context $\mathrm{c}$ corresponding to $<\underline{\mathrm{i}}, \underline{\mathrm{t}}, \underline{\mathrm{w}}>$ and [s $\left(t_{k}\right)$ isn't a part of $\mathrm{s}\left(t_{k^{*}}\right)(\mathrm{c})$ or $\mathrm{s}\left(t_{k^{*}}\right)$ isn't vivid for $\left.\mathrm{c}\right]$.

Otherwise fut $_{k^{*}}, i\left(\square\right.$ denotes $_{\mathrm{s}, \mathrm{c}^{*}} \mathrm{~s}\left(x_{k^{*}}\right)\left(\mathrm{s}\left(c_{i}\right)\right)$

口 Truth

Same rules as in A.

\section{Examples}

In the following examples, a. is the English sentence to be analyzed, $b$. its counterpart produced by the fragment in A., c. the result of applying the De Re Transformation to $\mathrm{b}$. The truth-conditions of $\mathrm{c}$. are given in $\mathrm{d}$., while the pronunciation is found in e.

(vi) Tense Agreement and a De Re pronoun

a. He thought that she was pregnant (De Re for the embedded she, De Se for the embedded past tense)

b. he think-past $_{1}-$ ind $_{1}$ that $_{\mathrm{c}_{1} \mathrm{~F}}$ she $_{2}$ be-pregnant- $\mathrm{c}_{1}{ }_{\mathrm{T}}^{\mathrm{F}}-\mathrm{c}_{1}{ }_{\mathrm{W}}^{\mathrm{F}}$, with $\mathrm{F}=<$ he, past, ind $>$

c. he think-past $_{1}-$ ind $_{1}$ that $_{\mathrm{c}_{1} \mathrm{~F}}$ she $_{2^{*}, 1}$ be-pregnant-c ${ }_{1}^{\mathrm{F}}-\mathrm{c}_{1}{ }_{\mathrm{W}}^{\mathrm{F}}$, with $\mathrm{F}=<$ he, past, ind $>$

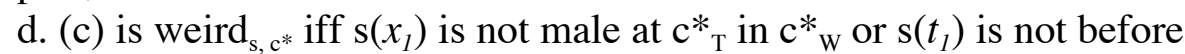
$\mathrm{c}^{*}{ }_{\mathrm{T}}$ or $\mathrm{s}\left(w_{1}\right)$ is not $\mathrm{c}^{*}{ }_{\mathrm{w}}$ or there is an attitude of thinking by $\mathrm{s}\left(x_{1}\right)$ at $\mathrm{s}\left(t_{1}\right)$ in $\mathrm{s}\left(w_{l}\right)$ and for some $\mathrm{c}^{\prime}$ in think $\mathrm{k}^{<\left(x_{I}\right), \mathrm{s}(t), \mathrm{s}\left(w_{I}\right)>}$ :

(i) $\mathrm{s}\left(x_{2}\right)$ is not female at $\mathrm{c}^{*}{ }_{\mathrm{T}}$ in $\mathrm{c}^{*}{ }_{\mathrm{w}}$, or

(ii) there is a context $\mathrm{c}$ corresponding to

$<\mathrm{s}\left(x_{1}\right), \mathrm{s}\left(t_{1}\right), \mathrm{s}\left(w_{1}\right)>$ and $\left[\mathrm{s}\left(x_{2^{*}}\right)\right.$ isn't vivid for $\mathrm{c}$ or $\mathrm{s}\left(x_{2}\right)$ is not a part of $\left.\mathrm{s}\left(x_{2^{*}}\right)(\mathrm{c})\right]$.

Otherwise (c) is true ${\mathrm{s}, \mathrm{c}^{*}}$ iff there is an attitude of thinking by $\mathrm{s}\left(x_{1}\right)$ at $\mathrm{s}\left(t_{1}\right)$ in $\mathrm{s}\left(w_{l}\right)$ and for every context $\mathrm{c}^{\prime}$ in think ${ }^{<\mathrm{s}\left(x_{I}\right), \mathrm{s}(t I), \mathrm{s}\left(w_{I}\right)>},<\mathrm{s}\left(x_{2^{*}}\right)\left(\mathrm{c}^{\prime}\right), \mathrm{c}_{\mathrm{T}}^{\prime}$, $\mathrm{c}^{\prime}{ }_{\mathrm{W}}>$ satisfies be-pregnant.

e. Pronunciation: he think-past-ind that she be-pregnant-past-ind 
Note: In the 'weirdness' conditions, the quantification over contexts in think $^{\left\langle s\left(x_{I}\right), \mathrm{s}\left(t_{1}\right), \mathrm{s}\left(w_{I}\right)>\right.}$ is in this case vacuous and could thus be eliminated.

(vii) A Double Access Reading with Tense a. He thought that she is pregnant (De Re for the embedded she and for the embedded present tense)

b. he think-past $_{1}-$ ind $_{1}$ that $_{\mathrm{c}_{1} \mathrm{~F}}$ she $_{2}$ be-pregnant-pres ${ }_{2}-\mathrm{c}_{1}{ }_{\mathrm{W}}^{\mathrm{F}}$, with $\mathrm{F}=<$ he, past, ind $>$

c. he think-past $_{1}$-ind that $_{\mathrm{c}_{1} \mathrm{~F}}$ she $_{2^{*}, 1}$ be-pregnant-pres $2_{2^{*}, 1}-\mathrm{c}_{1}{ }_{\mathrm{W}}^{\mathrm{F}}$, with $\mathrm{F}=<$ he, past, ind $>$

d. (c) is weird ${ }_{\mathrm{s}, \mathrm{c}^{*}}$ iff $\mathrm{s}\left(x_{l}\right)$ is not male at $\mathrm{c}^{*}{ }_{\mathrm{T}}$ in $\mathrm{c} *{ }_{\mathrm{w}}$ or $\mathrm{s}\left(t_{l}\right)$ is not before $\mathrm{c}^{*}{ }_{\mathrm{T}}$ or $\mathrm{s}\left(w_{l}\right)$ is not $\mathrm{c}{ }_{\mathrm{w}}$ or there is an attitude of thinking by $\mathrm{s}\left(x_{1}\right)$ at $\mathrm{s}\left(t_{l}\right)$ in $\mathrm{s}\left(w_{l}\right)$ and for some $\mathrm{c}^{\prime}$ in think $\mathrm{k}^{<\left(x_{I}\right), \mathrm{s}\left(t_{l}\right), \mathrm{s}\left(w_{l}\right)>}$ :

(i) $\mathrm{s}\left(x_{2}\right)$ is not female at $\mathrm{c}^{*}$ in $\mathrm{c}^{*}{ }_{\mathrm{w}}$, or

(ii) there is a context c corresponding to

$<\mathrm{s}\left(x_{1}\right), \mathrm{s}\left(t_{1}\right), \mathrm{s}\left(w_{1}\right)>$ and [ $\mathrm{s}\left(x_{2^{*}}\right)$ isn't vivid for $\mathrm{c}^{\prime}$ or $\mathrm{s}\left(x_{2}\right)$ is not a part of $\left.\mathrm{s}\left(x_{2^{*}}\right)(\mathrm{c})\right]$, or

(i') $\mathrm{s}\left(t_{2}\right)$ is not $\mathrm{c}^{*}{ }_{\mathrm{T}}$, or

(ii') there is a context c corresponding to $<\mathrm{s}\left(x_{1}\right), \mathrm{s}\left(t_{1}\right), \mathrm{s}\left(w_{1}\right)>$ and [ $\mathrm{s}\left(t_{2^{*}}\right)$ isn't vivid for $\mathrm{c}$ or $\mathrm{s}\left(t_{2}\right)$ is not a part of $\left.\mathrm{s}\left(t_{2 *}\right)(\mathrm{c})\right]$, or

(iii') $\mathrm{s}\left(t_{2^{*}}\right)\left(\mathrm{c}^{\prime}\right)$ is entirely after $\mathrm{c}_{\mathrm{T}}^{\prime}$

Otherwise (c) is true ${\mathrm{s}, \mathrm{c}^{*}}$ iff there is an attitude of thinking by $\mathrm{s}\left(x_{l}\right)$ at $\mathrm{s}\left(t_{l}\right)$ in $\mathrm{s}\left(w_{l}\right)$ and for every context $\mathrm{c}^{\prime}$ in think $\mathrm{k}^{<\mathrm{s}(x I), \mathrm{s}(t I), \mathrm{s}\left(w_{I}\right)>},<\mathrm{s}\left(x_{2^{*}}\right)\left(\mathrm{c}^{\prime}\right)$, $\mathrm{s}\left(t_{2^{*}}\right)\left(\mathrm{c}^{\prime}\right), \mathrm{c}_{\mathrm{W}}^{\prime}>$ satisfies be-pregnant.

e. Pronunciation: he think-past-ind that she be-pregnant-pres-ind

Note: In the 'weirdness' conditions the quantification over contexts in think $^{\left\langle\mathrm{s}\left(x_{I}\right), \mathrm{s}\left(t_{I}\right), \mathrm{s}\left(w_{I}\right)\right\rangle}$ is in this case not vacuous, since clause (iii') (the Upper Limit Constraint) depends on it.

(viii) A (failed) Forward Shifted Reading

a. \#He thought (in 1990) that she was pregnant (in 2000) (De Re for the embedded she and for the embedded past tense)

b. he think-past $_{1}-$ ind $_{1}$ that $_{\mathrm{c}_{1} \mathrm{~F}}$ she $_{2}$ be-pregnant-past ${ }_{2}-\mathrm{c}_{1}{ }^{\mathrm{F}}$, with $\mathrm{F}=<$ he, past, ind $>$

c. he think-past $_{1}$-ind that $_{\mathrm{c}_{1} \mathrm{~F}}$ she $_{2^{*}, 1}$ be-pregnant-past $2_{2^{*}, 1}-\mathrm{c}_{1}{ }_{\mathrm{W}}^{\mathrm{F}}$, with $\mathrm{F}=<$ he, past, ind $>$

$\mathrm{d}$. (c) is weird ${\mathrm{s}, \mathrm{c}^{*}}$ iff $\mathrm{s}\left(x_{1}\right)$ is not male at $\mathrm{c}^{*}{ }_{\mathrm{T}}$ in $\mathrm{c}^{*}{ }_{\mathrm{w}}$ or $\mathrm{s}\left(t_{1}\right)$ is not before $\mathrm{c}^{*}{ }_{\mathrm{T}}$ or $\mathrm{s}\left(w_{l}\right)$ is not $\mathrm{c}{ }_{\mathrm{w}}$ or there is an attitude of thinking by $\mathrm{s}\left(x_{1}\right)$ at $\mathrm{s}\left(t_{l}\right)$ in $\mathrm{s}\left(w_{l}\right)$ and for some $\mathrm{c}^{\prime}$ in think $\mathrm{k}^{<(x l), \mathrm{s}(t), \mathrm{s}\left(w_{l}\right)>}$ :

(i) $\mathrm{s}\left(x_{2}\right)$ is not female at $\mathrm{c}^{*}$ in $\mathrm{c}^{*}{ }_{\mathrm{w}}$, or

(ii) there is a context $\mathrm{c}$ corresponding to 
$<\mathrm{s}\left(x_{1}\right), \mathrm{s}\left(t_{1}\right), \mathrm{s}\left(w_{1}\right)>$ and $\left[\mathrm{s}\left(\mathrm{x}_{2^{*}}\right)\right.$ isn't vivid for $\mathrm{c}$ or $\mathrm{s}\left(x_{2}\right)$ is not a part of $\left.\mathrm{s}\left(x_{2^{*}}\right)(\mathrm{c})\right]$, or

(i') $\mathrm{s}\left(t_{2}\right)$ is not before $\mathrm{c}^{*}$, or

(ii') there is a context c corresponding to

$<\mathrm{s}\left(x_{1}\right), \mathrm{s}\left(t_{1}\right), \mathrm{s}\left(w_{1}\right)>$ and $\left[\mathrm{s}\left(t_{2^{*}}\right)\right.$ isn't vivid for $\mathrm{c}$ or $\mathrm{s}\left(t_{2}\right)$ is not a part of $\left.\mathrm{s}\left(t_{2 *}\right)(\mathrm{c})\right]$, or

(iii') $\mathrm{s}\left(t_{2^{*}}\right)\left(\mathrm{c}^{\prime}\right)$ is entirely after $\mathrm{c}_{\mathrm{T}}^{\prime}$

e. Pronunciation: he think-past-ind that she be-pregnant-pres-ind

Note: For the sentence to be acceptable $\mathrm{s}\left(t_{2^{*}}\right)$ must be such that: (i) $\mathrm{s}\left(t_{2^{*}}\right)\left(\mathrm{c}^{\prime}\right)$ does not lie after $\mathrm{c}_{\mathrm{T}}^{\prime}$, for each $\mathrm{c}^{\prime}$ in think $\mathrm{k}^{<\mathrm{s}(x I), \mathrm{s}(t), \mathrm{s}(w I)>}$, and (ii) $\mathrm{s}\left(t_{2^{*}}\right)(\mathrm{c})$ includes $s\left(t_{2 *}\right)$ (i.e. yesterday), where $c$ is the context corresponding to the agent's attitude. Thus if the agent is not mistaken about the time (i.e. if for each $c^{\prime}$ in think $\mathrm{k}^{<\left(x_{l}\right), \mathrm{s}\left(t_{l}\right), \mathrm{s}\left(w_{l}\right)>} \mathrm{c}_{\mathrm{T}}^{\prime}=\mathrm{s}\left(t_{l}\right)$, which is ten years ago), his thought must be that the woman's pregnancy spans ten years, which is not reasonable. This accounts for the deviance of the example.

(ix) A (successful) Forward Shifted Reading

a. He thought (in 1990) that she would be pregnant (in 2000) (De Re for the embedded she and for the embedded past tense)

b. he think-past $_{1}-$ ind $_{1}$ that $_{\mathrm{c}_{1} \mathrm{~F}}$ she $_{2}$ be-pregnant-fut $\left(\mathrm{c}_{1}{ }_{\mathrm{T}}^{\mathrm{F}}\right)-\mathrm{c}_{1}{ }_{\mathrm{W}}^{\mathrm{F}}$, with $\mathrm{F}=<$ he, past, ind $>$

c. he think-past $_{1}$-ind that $_{\mathrm{c}_{1} \mathrm{~F}}$ she $_{2^{*}, 1}$ be-pregnant- fut $\left.\mathrm{2}^{*}, 1\left(\mathrm{c}_{1}{ }_{\mathrm{T}}\right)_{1}\right)-\mathrm{c}_{1}^{\mathrm{F}}$, with $\mathrm{F}=<$ he, past, ind $>$

$\mathrm{d}$. (c) is weird ${\mathrm{s}, \mathrm{c}^{*}}$ iff $\mathrm{s}\left(x_{1}\right)$ is not male at $\mathrm{c}^{*}{ }_{\mathrm{T}}$ in $\mathrm{c}^{*}{ }_{\mathrm{w}}$ or $\mathrm{s}\left(t_{1}\right)$ is not before $\mathrm{c}^{*}{ }_{\mathrm{T}}$ or $\mathrm{s}\left(w_{1}\right)$ is not $\mathrm{c}^{*}{ }_{\mathrm{W}}$ or there is an attitude of thinking by $\mathrm{s}\left(x_{1}\right)$ at $\mathrm{s}\left(t_{1}\right)$ in $\mathrm{s}\left(w_{l}\right)$ and for some $\mathrm{c}^{\prime}$ in think $\mathrm{k}^{<\left(x_{I}\right), \mathrm{s}\left(t_{l}\right), \mathrm{s}\left(w_{I}\right)>}$ :

(i) $\mathrm{s}\left(x_{2}\right)$ is not female at $\mathrm{c}^{*}$ in $\mathrm{c}^{*}{ }_{\mathrm{w}}$, or

(ii) there is a context c corresponding to

$<\mathrm{s}\left(x_{1}\right), \mathrm{s}\left(t_{1}\right), \mathrm{s}\left(w_{1}\right)>$ and $\left[\mathrm{s}\left(\mathrm{x}_{2^{*}}\right)\right.$ isn't vivid for $\mathrm{c}$ or $\mathrm{s}\left(x_{2}\right)$ is not a part of $\left.\mathrm{s}\left(\mathrm{x}_{2^{*}}\right)(\mathrm{c})\right]$, or

(i') $c_{1}^{F}{ }_{T}$ denotes ${ }_{\left.\mathrm{s}_{[} c_{1} \square \mathrm{c}^{\prime}\right], \mathrm{c}^{*}} \#$ (impossible), or

(ii') $\mathrm{s}\left(t_{2^{*}}\right)\left(\mathrm{s}\left(c_{1}\right)\right)$ is not after $\left(\mathrm{s}\left(c_{1}\right)\right)_{\mathrm{T}}$, or

(iii') there is a context c corresponding to

$<\mathrm{s}\left(x_{I}\right), \mathrm{s}\left(t_{1}\right), \mathrm{s}\left(w_{1}\right)>$ and [ $\mathrm{s}\left(t_{2^{*}}\right)$ isn't vivid for $\mathrm{c}$ or $\mathrm{s}\left(t_{2}\right)$ isn't a part of $\left.\mathrm{s}\left(t_{2^{*}}\right)(\mathrm{c})\right]$.

Otherwise (c) is true ${\mathrm{s}, \mathrm{c}^{*}}$ iff there is an attitude of thinking by $\mathrm{s}\left(x_{l}\right)$ at $\mathrm{s}\left(t_{l}\right)$ in $\mathrm{s}\left(w_{1}\right)$ and for every $\mathrm{c}^{\prime}$ in think $\mathrm{k}^{<(x I), \mathrm{s}(t), \mathrm{s}(w))>} \mathrm{s}\left(\mathrm{x}_{2^{*}}\right)(\mathrm{c})$ is pregnant at $\mathrm{s}\left(t_{2^{*}}\right)\left(\mathrm{c}^{\prime}\right)$ in $\mathrm{c}_{\mathrm{w}}^{\prime}$.

e. Pronunciation: he think-past-ind that she be-pregnant-fut(past)-ind 
Note: The Upper Limit Constraint does not play any role in this example because the embedded past tense of (viii) has been replaced with $f u t_{2}\left(c_{1}{ }_{T}\right)$ (pronounced as fut(past) because of the agreement rule).

(x) Mood Agreement

a. (Il faut qu') il pense qu'elle soit enceinte

(It is necessary that) he think-subj that she be-subj pregnant

b. he think-pres $_{1}-$ subj $_{1}$ that $_{\mathrm{c}_{1} \mathrm{~F}}$ she $_{2}$ be-pregnant- ${ }_{1}{ }_{\mathrm{T}}{ }^{-}{ }_{1}{ }_{1}{ }_{\mathrm{W}}$

c. he think-pres $_{1}-$ subj $_{1}$ that $_{\mathrm{c}_{1} \mathrm{~F}}$ she $_{2^{*}}$ be-pregnant-c ${ }_{1} \mathrm{~T}^{\mathrm{F}}-\mathrm{c}_{1}{ }_{\mathrm{W}}^{\mathrm{F}}$, with $\mathrm{F}=<$ he,

pres, subj>

d. (c) is weird ${ }_{\mathrm{s}, \mathrm{c}^{*}}$ iff $\mathrm{s}\left(x_{1}\right)$ is not male at $\mathrm{c}^{*}{ }_{\mathrm{T}}$ in $\mathrm{c}^{*}{ }_{\mathrm{W}}$ or $\mathrm{s}\left(t_{1}\right)$ is not $\mathrm{c}^{*}{ }_{\mathrm{T}}$ or there is an attitude of thinking by $\mathrm{s}\left(x_{1}\right)$ at $\mathrm{s}\left(t_{1}\right)$ in $\mathrm{s}\left(w_{1}\right)$ and for some $\mathrm{c}^{\prime}$ in think $^{<\mathrm{s}\left(x_{l}\right), \mathrm{s}(t), \mathrm{s}\left(w_{l}\right)>}$ :

(i) $\mathrm{s}\left(x_{2}\right)$ is not female at $\mathrm{c}^{*}{ }_{\mathrm{T}}$ in $\mathrm{c}^{*}{ }_{\mathrm{w}}$, or

(ii) there is a context c corresponding to $<\mathrm{s}\left(x_{1}\right)$,

$\mathrm{s}\left(t_{1}\right), \mathrm{s}\left(w_{1}\right)>$ and [ $\mathrm{s}\left(x_{2^{*}}\right)$ isn't vivid for $\mathrm{c}$ or $\mathrm{s}\left(x_{2}\right)$ is not a part of $\left.\mathrm{s}\left(\mathrm{x}_{2^{*}}\right)(\mathrm{c})\right]$.

Otherwise (c) is true ${\mathrm{s}, \mathrm{c}^{*}}$ iff there is an attitude of thinking by $\mathrm{s}\left(x_{1}\right)$ at $\mathrm{s}\left(t_{1}\right)$

in $\mathrm{s}\left(w_{l}\right)$ and for every context $\mathrm{c}^{\prime}$ in think ${ }^{<\mathrm{s}\left(x_{I}\right), \mathrm{s}(t I), \mathrm{s}\left(w_{I}\right)>},<\mathrm{s}\left(x_{2^{*}}\right)\left(\mathrm{c}^{\prime}\right), \mathrm{c}_{\mathrm{T}}^{\prime}$,

$\mathrm{c}^{\prime}{ }_{\mathrm{W}}>$ satisfies be-pregnant.

e. Pronunciation: he think-pres-subj that she be-pregnant-pres-subj

Note: Even if we had given a more sophisticated analysis of mood in which the subjunctive imposed some interpretive condition on world variables, this condition would not have been felt in this example because the features of the embedded subjunctive are present in the pronunciation only.

(xi) A Double Access Reading with Mood

a. (Il faut qu') il pense qu'elle est enceinte

(It is necessary that) he think-subj that she is-ind pregnant

b. he think-pres $_{1}-$ subj $_{1}$ that $_{\mathrm{c}_{1} \mathrm{~F}}$ she $_{2}$ be-pregnant-c ${ }_{1}^{\mathrm{F}} \mathrm{T}^{-}$-ind , with $^{\mathrm{F}}=<$ he, pres, subj>

c. he think-pres $_{1}-$ subj $_{1}$ that $_{\mathrm{c}_{1} \mathrm{~F}}$ she $_{2^{*}, 1}$ be-pregnant-c ${ }_{1} \mathrm{~T}^{-}$ind $_{2^{*}, 1}$, with $\mathrm{F}=<$ he, pres, subj $>$

$\mathrm{d}$. (c) is weird ${ }_{\mathrm{s}, \mathrm{c}^{*}}$ iff $\mathrm{s}\left(x_{1}\right)$ is not male at $\mathrm{c}^{*}{ }_{\mathrm{T}}$ in $\mathrm{c}^{*}{ }_{\mathrm{w}}$ or $\mathrm{s}\left(t_{1}\right)$ is not $\mathrm{c}^{*}{ }_{\mathrm{T}}$ or there is an attitude of thinking by $\mathrm{s}\left(x_{1}\right)$ at $\mathrm{s}\left(t_{1}\right)$ in $\mathrm{s}\left(w_{1}\right)$ and for some $\mathrm{c}^{\prime}$ in think $^{\left.<\mathrm{s}\left(x_{I}\right), \mathrm{s}\left(t_{l}\right), \mathrm{s}\left(w_{I}\right)\right\rangle}$ :

(i) $\mathrm{s}\left(x_{2}\right)$ is not female at $\mathrm{c}^{*}{ }_{\mathrm{T}}$ in $\mathrm{c}^{*}{ }_{\mathrm{w}}$, or

(ii) there is a context $\mathrm{c}$ corresponding to

$<\mathrm{s}\left(x_{1}\right), \mathrm{s}\left(t_{1}\right), \mathrm{s}\left(w_{1}\right)>$ and $\left[\mathrm{s}\left(\mathrm{x}_{2^{*}}\right)\right.$ isn't vivid for $\mathrm{c}$ or $\mathrm{s}\left(x_{2}\right)$ is not a part of $\left.\mathrm{s}\left(x_{2^{*}}\right)(\mathrm{c})\right]$, or

(i') $\mathrm{s}\left(w_{2}\right)$ is not $\mathrm{c}^{*}{ }_{\mathrm{w}}$, or

(ii') there is a context c corresponding to

$<\mathrm{s}\left(x_{1}\right), \mathrm{s}\left(t_{1}\right), \mathrm{s}\left(w_{1}\right)>$ and $\left[\mathrm{s}\left(w_{2^{*}}\right)\right.$ isn't vivid for $\mathrm{c}$ or $\mathrm{s}\left(w_{2}\right)$ is not a part of 
$\left.\mathrm{s}\left(w_{2 *}\right)(\mathrm{c})\right]$, or

(iii') $\mathrm{s}\left(w_{2 *}\right)\left(\mathrm{c}^{\prime}\right)$ does not contain $\mathrm{c}_{\mathrm{W}}^{\prime}$

Otherwise (c) is true ${\mathrm{s}, \mathrm{c}^{*}}$ iff there is an attitude of thinking by $\mathrm{s}\left(x_{l}\right)$ at $\mathrm{s}\left(t_{l}\right)$ in $\mathrm{s}\left(w_{1}\right)$ and for every context $\mathrm{c}^{\prime}$ in think ${ }^{\left.<\mathrm{s}\left(x_{I}\right), \mathrm{s}(t I)\right) \mathrm{s}\left(w_{I}\right)>},<\mathrm{s}\left(x_{2^{*}}\right)\left(\mathrm{c}^{\prime}\right), \mathrm{c}_{\mathrm{T}}^{\prime}$, $\mathrm{s}\left(w_{2^{*}}\right)\left(\mathrm{c}^{\prime}\right)>$ satisfies be-pregnant.

e. Pronunciation: he think-pres-subj that she be-pregnant-pres-ind

Note: It might be helpful to consider some values of $\mathrm{s}\left(w_{2^{*}}\right)$ that would be allowed by conditions (i')-(iii') above (since each of these is sufficient to trigger referential failure, $\mathrm{s}\left(w_{2^{*}}\right)$ is allowed by these conditions just in case it satisfies the conjunction of their negations). Suppose the agent of the attitude (call him 'John') thinks: 'Mary is pregnant in the worlds in which she displays the same symptoms as in this world'. Then the relevant description of worlds, $\mathrm{s}\left(w_{2^{*}}\right)$, is the function: $\square \mathrm{c}$ the group of all worlds w such that Mary displays in $\mathrm{w}$ the same symptoms as in $\mathrm{c}_{\mathrm{w}}$. On the assumption that $\mathrm{s}\left(w_{2^{*}}\right)$ is not ruled out by condition (i'), and thus that $\mathrm{s}\left(w_{2}\right)=\mathrm{c}^{*}{ }_{\mathrm{w}}$, we have that:

-Condition (iii') is automatically satisfied: for each $\mathrm{c}^{\prime}$ in think ${ }^{\left.<\mathrm{s}\left(x_{l}\right), \mathrm{s}\left(t_{l}\right), \mathrm{s}\left(w_{I}\right)\right\rangle}$, $\mathrm{s}\left(w_{2^{*}}\right)\left(\mathrm{c}^{\prime}\right)$ contains $\mathrm{c}^{\prime}{ }_{\mathrm{w}}$, since (vacuously) Mary displays in $\mathrm{c}^{\prime}{ }_{\mathrm{w}}$ the same symptoms as in $\mathrm{c}_{\mathrm{w}}^{\prime}$.

-If there is a context c corresponding to $\left\langle\mathrm{s}\left(x_{1}\right), \mathrm{s}\left(t_{1}\right), \mathrm{s}\left(w_{1}\right)>\right.$, Condition (ii') requires that $\mathrm{s}\left(w_{2}\right)$ (that is, $\left.\mathrm{c}^{*}{ }_{\mathrm{w}}\right)$ be part of $\mathrm{s}\left(w_{2^{*}}\right)(\mathrm{c})$, i.e. of the worlds in which Mary has the same symptoms as in $\mathrm{s}\left(w_{1}\right)$. In other words, Mary must display the same symptoms in $\mathrm{s}\left(w_{1}\right)$ as she does in the actual world $\mathrm{c}^{*}{ }_{\mathrm{w}}$.

On the assumption that the salient description of worlds $\mathrm{s}\left(w_{2^{*}}\right)$ is as above, we may apply a standard mechanism of presupposition projection to obtain the following result:

Presupposition: every world compatible with what the speaker considers to be desirable is one in which Mary has the same symptoms as in the actual world. Assertion: In every world compatible with what the speaker considers to be desirable, John thinks: 'Mary is pregnant in the worlds in which she displays the same symptoms as in this world ${ }^{20}$.

Arguably this is a correct result: to the extent that we have intuitions on (xi)a, it would appear that it is indeed presupposed that the speaker 'talks about' worlds in which Mary has the same symptoms as in the actual world.

\section{De Se Readings as a Species of De Re Readings}

\footnotetext{
${ }^{20}$ The present analysis would have to be extended to provide a full account of those examples in which the non-bracketed part of (xi)a is embedded in the antecedent of a counterfactual conditional, as in (32)b above.
} 
The vocabulary and syntax are the same as in Appendix B, except that the symbol '*' can optionally be replaced with the symbol ' + '. Everything else remains the same, except the definition of denotation, to which the following clause must be added:

$\square_{k+},{ }_{i}$ denotes $_{\mathrm{s}, \mathrm{c}^{*}} \#$ iff (i) $\square_{k}$ denotes $_{\mathrm{s}, \mathrm{c}^{*}} \#$, or

(ii) there is a context c corresponding to $<\underline{\mathrm{i}}, \underline{\mathrm{t}}, \underline{\mathrm{w}}>$ and $\left[\mathrm{s}\left(\square_{k}\right)\right.$ isn't a part of $\mathrm{s}\left(\square_{k^{*}}\right)(\mathrm{c})$ or $\mathrm{s}\left(\square_{k^{*}}\right)$ isn't vivid for $\left.\mathrm{c}\right]$, or

(iii) [D○\{pres, past $\}$ and $\mathrm{s}\left(\square_{k^{*}}\right)\left(\mathrm{s}\left(c_{i}\right)\right)$ is entirely after $\left.\left(\mathrm{s}\left(c_{i}\right)\right)_{\mathrm{T}}\right]$ or $\left[\square \square\{\right.$ ind $\}$ and $\left(\mathrm{s}\left(c_{i}\right)\right)_{\mathrm{W}}$ isn't a part of $\left.\mathrm{s}\left(\square_{k^{*}}\right)\left(\mathrm{s}\left(c_{i}\right)\right)\right]$, or

Otherwise $\square_{k^{*},{ }_{i}}$ denotes $_{\mathrm{s}, \mathrm{c}^{*}} \mathrm{~s}\left(x_{k^{*}}\right)\left(\mathrm{s}\left(c_{i}\right)\right)$

(iv) $\mathbf{s}\left(\square_{k^{*}}\right) \square\left\{\square \mathbf{c} \mathbf{c}_{\mathrm{A}}, \square \mathbf{c} \mathbf{c}_{\mathrm{T}}, \square \mathbf{c} \mathbf{c}_{\mathrm{w}}\right\}$

\section{$\underline{\text { Remarks }}$}

(i) As it stands the system will over-generate, since it has the resources to yield De Se readings in two distinct ways: (a) as before, through terms such as $c_{i}^{F}, c_{i}^{F}, c_{i}^{F}$, but also (b) through De Re terms with an additional constraint, of the form $\square_{k+},{ }_{i}$. We could decide to eliminate the diacritic $\mathrm{F}=<$ he, pres, ind $>$ and the context terms $c_{k A}^{F}, c_{k T}^{F}, c_{k W}^{F}$; this would have no undesirable consequences, except for the account of Kamp \& Rohrer's example in (iv), since the most embedded past tense features cannot be analyzed as being interpreted De Re (whether or not this De Re is of the De Se variety).

(ii) The system could be set up in a different way, by re-defining the notion of an assignment so that each variable $x_{i+}$ is assigned the value $\mathrm{s}\left(x_{i+}\right)=\square \mathrm{c} \mathrm{c} \mathrm{c}_{\mathrm{A}}$, each variable $t_{i+}$ is assigned the value $\mathrm{s}\left(t_{i+}\right)=\square \mathrm{c} \mathrm{c}_{\mathrm{T}}$, and each variable $w_{i_{+}}$is assigned the value $\mathrm{s}\left(w_{i+}\right)=\square \mathrm{c} \mathrm{c}_{\mathrm{W}}$. This would also emphasize the great similarity between, say, a term $x_{i+, \mathrm{k}}$ and the term $c^{F}{ }_{A}$ used in Appendix A and Appendix B.

(xii) a. He hopes that he is elected / He hopes that he himself is elected / He hopes to be elected (De Se Reading for each of the embedded arguments)

b. he think-pres $_{1}-$ ind $_{1}$ that $_{\mathrm{c}_{1} \mathrm{~F}}$ he $_{1}$ be-elected-pres -ind $_{1}$, with $\mathrm{F}=<$ he, pres, ind $>$

c. he think-past $_{1}-$ ind $_{1}$ that $_{\mathrm{c}_{1} \mathrm{~F}}$ he $_{1+, 1}$ be-elected-pres ${ }_{1+, 1}$-ind $_{1+, 1}$, with $\mathrm{F}=<$ he, past, ind $>$

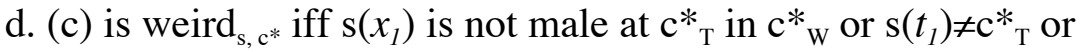
$\mathrm{s}\left(w_{1}\right) \neq \mathrm{c} *{ }_{\mathrm{w}}$ or there is an attitude of thinking by $\mathrm{s}\left(x_{1}\right)$ at $\mathrm{s}\left(t_{1}\right)$ in $\mathrm{s}\left(w_{1}\right)$ and for some $\mathrm{c}^{\prime}$ in think $\mathrm{k}^{<(x I), \mathrm{s}(t), \mathrm{s}(w])>}$ : 
(redundant), or

(i) $\mathrm{s}\left(x_{1}\right)$ is not male at $\mathrm{c}_{\mathrm{T}}$ in $^{*}{ }_{\mathrm{W}}$

(ii) there is a context c corresponding to $<\mathrm{s}\left(x_{1}\right), \mathrm{s}\left(t_{1}\right), \mathrm{s}\left(w_{1}\right)>$ and $\left[\mathrm{s}\left(x_{1^{*}}\right)\right.$ isn't vivid for $\mathrm{c}$ or $\mathrm{s}\left(x_{1}\right)$ is not a part of $\left.\mathrm{s}\left(x_{1^{*}}\right)(\mathrm{c})\right]$, or

(iii) $\mathrm{s}\left(x_{I^{*}}\right) \square\left\{\square \mathrm{c} \mathrm{c}_{\mathrm{A}}, \square \mathrm{c} \mathrm{c}_{\mathrm{T}}, \square \mathrm{c} \mathrm{c}_{\mathrm{W}}\right\}$ (since $\mathrm{s}\left(x_{1^{*}}\right)$ is a function from contexts to individuals, it could only be identical to $\square \mathrm{c}_{\mathrm{A}}$ )

(i') $\mathrm{s}\left(t_{1}\right)$ is not $\mathrm{c}_{\mathrm{T}}^{*}$, (redundant), or

(ii') there is a context $\mathrm{c}$ corresponding to $<\mathrm{s}\left(x_{1}\right), \mathrm{s}\left(t_{1}\right), \mathrm{s}\left(w_{1}\right)>$ and $\left[\mathrm{s}\left(t_{1^{*}}\right)\right.$ isn't vivid for $\mathrm{c}$ or $\mathrm{s}\left(t_{1}\right)$ is not a part of $\left.\mathrm{s}\left(t_{1^{*}}\right)(\mathrm{c})\right]$, or

(iii') $\mathrm{s}\left(t_{1^{*}}\right)\left(\mathrm{c}^{\prime}\right)$ is entirely after $\mathrm{c}_{\mathrm{T}}^{\prime}$

(iv') $\mathrm{s}\left(t_{1^{*}}\right) \square\left\{\square \mathrm{c} \mathrm{c}_{\mathrm{A}}, \square \mathrm{c} \mathrm{c}_{\mathrm{T}}, \square \mathrm{c}_{\mathrm{w}}\right\}$ (since $\mathrm{s}\left(t_{1^{*}}\right)$ is a function from contexts to moments, it could only be identical to $\square \mathrm{c} \mathrm{c}_{\mathrm{T}}$,), or

(i") $\mathrm{s}\left(w_{l}\right.$ is not $\mathrm{c}^{*}{ }_{\mathrm{w}}$, (redundant) or

(ii") there is a context c corresponding to $<\mathrm{s}\left(x_{1}\right), \mathrm{s}\left(t_{1}\right), \mathrm{s}\left(w_{1}\right)>$ and $\left[\mathrm{s}\left(w_{1^{*}}\right)\right.$ isn't vivid for $\mathrm{c}$ or $\mathrm{s}\left(w_{1}\right)$ is not a part of $\left.\mathrm{s}\left(w_{1 *}\right)(\mathrm{c})\right]$, or

(iii") $\mathrm{s}\left(w_{l^{*}}\right)\left(\mathrm{c}^{\prime}\right)$ does not contain $\mathrm{c}_{\mathrm{W}}^{\prime}$ (iv") $\mathrm{s}\left(w_{I^{*}}\right) \square\left\{\square \mathrm{c} \mathrm{c}_{\mathrm{A}}, \square \mathrm{c}_{\mathrm{T}}, \square \mathrm{c} \mathrm{c}_{\mathrm{W}}\right\}$ (since $\mathrm{s}\left(w_{1^{*}}\right)$ is a function from contexts to worlds, it could only be identical to $\left.\square \mathrm{c}_{\mathrm{w}},\right)$

Otherwise (c) is true ${ }_{\mathrm{s}, \mathrm{c}^{*}}$ iff there is an attitude of thinking by $\mathrm{s}\left(x_{1}\right)$ at $\mathrm{s}\left(t_{l}\right)$ in $\mathrm{s}\left(w_{l}\right)$ and for every context $\mathrm{c}^{\prime}$ in think $\mathrm{k}^{<(x I), \mathrm{s}(t), \mathrm{s}\left(w_{l}\right)>},<\mathrm{s}\left(x_{l^{*}}\right)\left(\mathrm{c}^{\prime}\right)$, $\mathrm{s}\left(t_{l^{*}}\right)\left(\mathrm{c}^{\prime}\right), \mathrm{s}\left(w_{1^{*}}\right)\left(\mathrm{c}^{\prime}\right)>$, i.e. when the sentence is not weird ${\mathrm{s}, \mathrm{c}^{*}}$ (because $\mathrm{s}\left(x_{I^{*}}\right), \mathrm{s}\left(t_{I^{*}}\right), \mathrm{s}\left(w_{l^{*}}\right)$ must be $\square \mathrm{c} \mathrm{c}_{\mathrm{A}}, \square \mathrm{c}_{\mathrm{T}}, \square \mathrm{c}_{\mathrm{W}}$ respectively) $<\mathrm{c}_{\mathrm{A}}^{\prime}, \mathrm{c}_{\mathrm{T}}^{\prime}$, $\mathrm{c}_{\mathrm{W}}^{\prime}>$ satisfies be-elected.

e. Pronunciation: he think-past-ind that he be-elected-pres-ind

\section{References}

Abusch, Dorit (1997) 'Sequence of Tense and Temporal De Re', Linguistics \& Philosophy 20: 1-50

Anderson, A. (1951) 'A Note on Subjunctive and Counterfactual Conditionals', Analysis 12: 35-8

Bittner, Maria (2001) 'Topic Referents for Individuals and Possibilities', Proceedings of SALT XI.

Chierchia, Gennaro (1987) 'Anaphora and Attitudes De Se', in Bartsch, van Benthem \& van Emde Boas (eds), Language in Context, Dordrecht, Netherlands: Foris. 
Clements, George N. (1975) 'The logophoric pronoun in Ewe: Its role in discourse', Journal of West African Languages 10: 141-77

Cooper, Robin (1983) Quantification and Syntactic Theory, Reidel.

Cresswell, Maxwell (1990) Entities and Indices, Kluwer

Enç, Mürvet (1987) 'Anchoring Conditions for Tense', Linguistic Inquiry 18, 4.

Fauconnier, Gilles (1975). 'Do Quantifiers Branch?'. Linguistic Inquiry, Volume 6, 4, 555-578.

Fintel, Kai von (1997) 'The Presupposition of Subjunctive Conditionals', MIT Working Papers in Linguistics 25, eds. Orin Percus and Uli Sauerland.

Heim, Irene (1982) The Semantics and Definite and Indefinite Noun Phrases, Ph.D Dissertation, University of Massachusetts, Amherst.

Heim, Irene (1983) 'On the Projection Problem for Presuppositions', Proceedings of WCCFL 2, Stanford University, 114-125.

Heim, Irene (1990) 'E-Type Pronouns and Donkey Anaphora', Linguistics and Philosophy 13, 2: 137-177.

Heim, Irene (1991). 'Artikel und Definitheit.' In A. v. Stechow and D. Wunderlich (eds) Handbuch der Semantik. Berlin: de Gruyter, 1991.

Heim, Irene (1992) 'Presupposition projection and the semantics of attitude verbs', Journal of Semantics 9.

Heim, Irene (1994a) 'Puzzling reflexive pronouns in de se reports', hand-out, Bielefeld Conference, March 1994.

Heim, Irene (1994b) 'Comments on Abusch's Theory of Tense', in H. Kamp (ed.), Ellipsis, Tense and Questions, pp. 143-170, U. of Amsterdam.

Heim, Irene \& Angelika Kratzer (1998) Semantics in Generative Grammar. Oxford: Blackwell

Heim, Irene (2002) 'Features of Pronouns in Semantics and Morphology', hand-out of a talk given at USC on 01.31.02.

Iatridou, Sabine (2000) 'The Grammatical Ingredients of Counterfactuality', Linguistic Inquiry, 31, 2: 231-270

Kamp, Hans (1981) 'A Theory of Truth and Semantic Representation', in J. Groenendijk, T. Janssen \& M. Stokhof (eds) Formal Methods in the Study of Language, Amsterdam. Reprinted in J. Groenendijk, T. Janssen \& M. Stokhof (eds) Truth, Interpretation and Information, Dordrecht: Foris 1-41.

Kaplan, David (1969) 'Quantifying In', in Words and Objections, ed. D. Davidson \& J. Hintikka, Dordrecht: Reidel.

Kratzer, Angelika (1998) 'More Structural Analogies Between Pronouns and Tenses', Proceedings of SALT VIII

Ludlow, Peter (1994) 'Conditionals, Events, and Unbound Pronouns', Lingua e Stile 29: 165-183.

Morgan, Jerry (1970) 'On the Criterion of Identity for Noun Phrase Deletion', CLS 6, University of Chicago.

Ogihara, Toshiyuki (1996) Tense, Attitudes, and Scope, Kluwer Academic Publishers. 
Ogihara, Toshiyuki (2000) 'Double-Access Sentences Generalized', Proceedings from Semantics and Linguistic Theory IX (SALT9), CLC Publications, Cornell University, pp. 224-236.

Partee, Barbara (1973) 'Some Structural Analogies Between Tenses and Pronouns in English', The Journal of Philosophy 70, 601-609.

Partee, Barbara (1984) 'Nominal and Temporal Anaphora', Linguisics \& Philosophy 7, 243-286.

Percus, Orin \& Uli Sauerland (2002) ' The Syntax of Attitude Reports and the Semantics of Pronouns', manuscript, University of Tübingen

Quine, W. V. (1956) 'Quantifiers and Propositional Attitudes', Journal of Philosophy, 53.

Reinhart, Tanya (1997). 'Quantifier Scope: How Labor is Divided between QR and Choice Functions', Linguistics and Philosophy 20:335-397.

Schein, Barry (1993) Plurals and Events, MIT Press

Schein, Barry (2001) 'Adverbial, Descriptive Reciprocals', to appear in Proceedings of SALT XI.

Schlenker, Philippe (1999) Propositional Attitudes and Indexicality (A CrossCategorial Approach), Ph.D thesis, MIT

Schlenker, Philippe (2002a) 'A Plea for Monsters', to appear, Linguistics and Philosophy

Schlenker, Philippe (2002b) 'Conditionals as Definite Descriptions (A Referential Analysis)', to appear, Journal of Language \& Computation, special issue on Choice Functions in Natural Language (ed. R. Kempson \& K. von Heusinger).

Schlenker, Philippe (2002c) 'Indexicality, Logophoricity, and Plural Pronouns', to appear, Proceedings of the Fifth Conference on Afroasiatic Languages, Benjamins.

Stalnaker, Robert (1968) 'A Theory of Conditionals', in Studies in Logical Theory, American Philosophical Quaterly, Monograph: 2.

Stalnaker, Robert (1975) 'Indicative Conditionals', Philosophia 5: 269-86

Stechow, Arnim von (2002) 'Binding by Verbs: Tense, Person and Mood under Attitudes', ms., University of Tübingen.

Stone, Matthew (1997) 'The Anaphoric Parallel between Modality and Tense', IRCS Report 97-06, University of Pennsylvania 